\title{
El proyecto "Ciudad del Viento", Portal Bicentenario, Cerrillos: fecundidad de una idea modelo de diseño urbano sustentable
}

A study case of sustainable urban design: Wind City, transformation of an airport in Cerrillos, Santiago de Chile

\section{Autor}

Rubén González Aguayo

\section{Filiación}

Ucinf - AHC

a_revista@hotmail.com

\section{Resumen}

A propósito de la oportunidad de reconstrucción del país, post terremoto 2010, y de la evaluación del proyecto ciudad parque, se analiza la propuesta ganadora del Primer Premio del Concurso Internacional de Ideas Portal Bicentenario, "Ciudad del Viento", emplazada en el ex Aeródromo de Cerrillos en Santiago de Chile, en cuanto modelo de urbanización sustentable.

\section{Palabras clave}

Reutilización de infraestructura urbana; Diseño Urbano; Cerrillos, Santiago de Chile;

\section{Abstract}

The reconstruction after de 8.8 earthquake in Chile is an opportunity to review the winner project of the contest "Ciudad Portal Bicentenario", transformation of Cerrillos Airport into a new sustainable city.

\section{Keywords}

Airport Redevelopment; Urban Design; Cerrillos, Santiago de Chile.

\section{Sumario}

Introducción: la transformación del aeródromo cerrillos en un proyecto urbano.

1. La propuesta original "Ciudad del Viento" como modelo de urbanización sostenible.

2. Fecundidad de la idea "Ciudad del Viento".

3. Cabe resumir y reflexionar

Bibliografía

Anexo 1.-

Anexo 2.- 


\section{Introducción: la transformación del aeródromo cerrillos en un proyecto urbano.}

La propuesta que se examina, elaborada por el autor de esta comunicación, en coautoría con Cristian Ulloa Muñoz en 2001 y emplazada en el ex aeródromo Cerrillos en Santiago de Chile, fue el resultado de un concurso internacional público y abierto, al que se presentaron 72 propuestas. La propuesta referida se Ilamó "Ciudad del Viento".

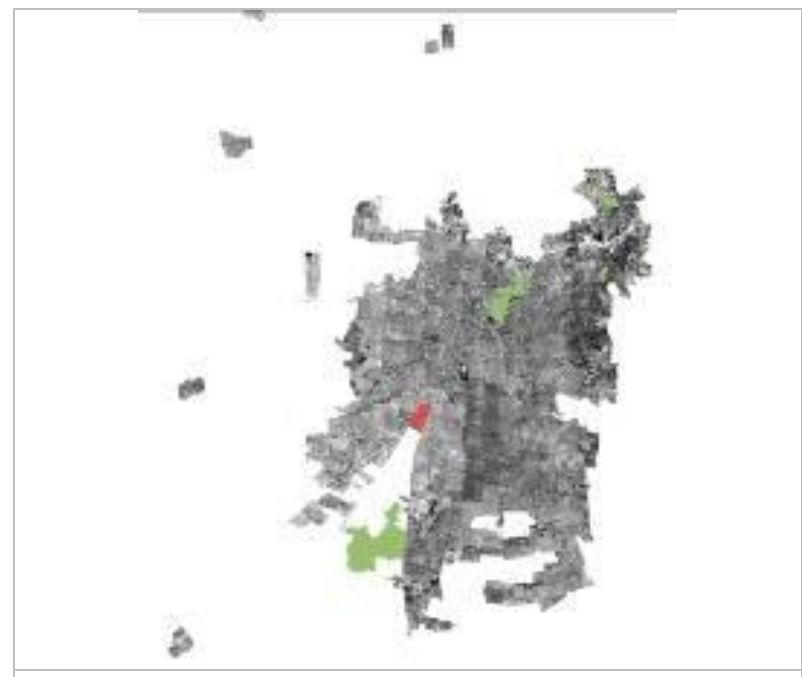

Fig.1.- Ubicación terreno (en rojo) en Cerrillos. Elaboración González R.; Ulloa C.; 2001, documentos presentados Concurso Ideas Portal Bicentenario, en base a foto SAF año 2000.

El terreno en cuestión, un polígono vacío de 245 hás, rodeado por la ciudad consolidada por tres de sus lados, está ubicado en la Comuna de Cerrillos, la que se emplaza en la cabecera del arco sur poniente del Área Metropolitana de Santiago (AMS). Cerrillos, tiene superficie de 16,75 kilómetros cuadrados, y se encuentra, en su totalidad, dentro de los límites del área urbana del AMS. Con una población estimada al año 2001 de 78.698 habitantes, presenta al momento de plantearse el Concurso de Ideas, una densidad de 49,18 hab/há, a duplicar con la ejecución del proyecto, para el que las bases técnicas del concurso solicitaron la incorporación de 15.000 viviendas (MINVU, 2001). El sitio del proyecto, ubicado en el límite oriente de Cerrillos queda inmediato a dos de las comunas más pobres del AMS: Pedro Aguirre Cerda y Lo Espejo. El terreno estaba en 2001 rodeado en tres de sus lados por áreas urbanas consolidadas, mientras que en su proyección sur -producto de las restricciones sobre la edificabilidad por el uso aeroportuario, así como por la dinámica urbana propia de ese 
sector de la ciudad- existe un terreno de carácter periurbano, con usos agrícolas e industriales.

En el año 2001, el Ministerio de Vivienda y Urbanismo (MINVU) en conjunto con el Colegio de Arquitectos de Chile (COARQ) organizaron un Concurso Internacional de Ideas que fue dirigido por el arquitecto Humberto Eliash y se constituyó un directorio donde estaba representado el Gobierno, los Ministerios de Obras Públicas y Vivienda, la Comisión Bicentenario y la Municipalidad de Cerrillos. Se recibieron proyectos de América, Europa y Asia y, además del proyecto ganador, se asignaron un segundo lugar a Serex una consultora de la Universidad Católica de Chile y un tercer lugar para la oficina del Arqto. Mario Pérez de Arce, una prestigiosa oficina de arquitectos chilena (Eliash, H., 2006).

En 2002, posteriormente a la definición del proyecto ganador, el MINVU, a través del Ministro de la época, Jaime Ravinet y el gerente del proyecto Pablo Trivelli, organizó una licitación pública para la ejecución de un Plan Maestro Urbano de carácter flexible, en el que se definiría el proceso del diseño urbano del Plan, el modelo de gestión y la estrategia de implementación. Esta licitación tuvo como contraparte al MINVU, asesorado por un equipo de especialistas externo, constituido por el arquitecto argentino Alfredo Garay, y los arquitectos chilenos Germán Bannen y Humberto Eliash; la Comuna de Cerrillos estuvo representada por el arquitecto Patricio Salazar" (Eliash, H., 2006).

Las bases licitación para el Plan Maestro plantearon la necesidad de un proyecto que guiara el desarrollo de la gestión urbana posterior mediante la elaboración de diagnósticos urbanos e inmobiliarios, de servicios, transporte, los proyectos asociados y etapas para la adecuada gestión futura de los paños (MINVU 2002). Se consideró entonces que la propuesta ganadora del Concurso Internacional de Ideas no era necesariamente vinculante con la propuesta final a ser obtenida como producto del Plan Maestro Urbano licitado (MINVU 2002). Esto significó que el desarrollo del Plan Maestro no avanzaría en la línea de factibilizar la propuesta original ganadora del Concurso Internacional, ajustándola a las condiciones específicas del terreno, y desarrollándola técnicamente, sino que dejó abierta la posibilidad de su modificación. Estas bases consideraron a la propuesta ganadora como un referente, al igual que el segundo y tercer lugar y, por tanto, relativizaron su contenido conceptual.

El Plan Maestro fue adjudicado en segunda instancia por la Asociación Portal Bicentenario, un consorcio de ocho consultoras (siete chilenas y dos argentinas), con un equipo asesor experto nacional e internacional. Su propuesta para el área fue el resultado de más de dos años de trabajo (entre 2003 y 2005) y de una serie de articulaciones y acuerdos entre el mandante público y el equipo privado que lo desarrolló. El resultado modificó el sentido original de la propuesta, con un proyecto que rescató algunos de los elementos estructurales básicos del proyecto ganador del concurso de ideas ""Ciudad del Viento"" -en términos de estructura urbana de las áreas verdes-, sin embargo, terminó por alterar su sentido profundo respecto de ser un 
modelo de urbanización sostenible. El proceso de modificación fue liderado por la empresa Urbe arquitectos.

En paralelo al desarrollo del Plan Maestro, se desarrollaron algunos concursos públicos que se fueron sumando a la formulación del Plan Maestro y a la imagen objetivo definitiva para el área:

En 2004, "la Intendencia Metropolitana en conjunto con el COARQ y la Corporación de Fomento (CORFO), organizaron un concurso de ideas para emplazar en la propuesta un recinto ferial y centro de convenciones para Santiago", proyecto ganado por la oficina WAR y que se sumó al Plan Maestro generado por la Asociación Portal Bicentenario, sin formar parte condicionante del proyecto ya que se consideró que dependería "de los posibles concesionarios la decisión final de su ubicación y diseño" (Eliash, H., 2006). Lamentablemente, este proyecto tampoco rescató el espíritu de la propuesta original como veremos más adelante.

"A fines del año 2004 se organizó un concurso para el diseño del parque de setenta hectáreas. Se presentaron siete proyectos, de Chile, Argentina y Brasil, resultando ganador el proyecto de la oficina chilena Montealegre y Beach" (Eliash H, 2006). Dicho proyecto se encuentra hoy en etapa de construcción. Esta propuesta recoge conceptualmente sólo algunos de los aspectos presentados en el diseño original del proyecto, como se verá más adelante.

El reemplazo del diseño original para el área, en conjunto con aspectos comunicacionales necesarios para el relanzamiento de la propuesta implicó que posteriormente se renombrara a la iniciativa como "Ciudad Parque Bicentenario" (CPB) nombre con el que se le conoce al proyecto a la fecha.

Posteriormente, en febrero del 2008, se adjudicó el proyecto Centro Cívico Portal Bicentenario al equipo profesional compuesto por Eliash arquitectos en conjunto con Carlos Martner, Carolina Devoto, Núcleo Paisajismo y Montalva Quindos Propiedades. Este proyecto, como también veremos más adelante, recuperó algunas de las ideas presentadas en el diseño original.

A mediados del 2009 se organizó un concurso abierto para el desarrollo de Comunidades de Ingresos Diversos, en uno de los macrolotes del límite sur de la propuesta. Este concurso retomó algunos de los aspectos del proyecto original.

El costo estimado del proyecto al momento de encontrarse diseñado el Plan Maestro es de 100.000.000 de dólares. CPB actualmente se encuentra con su ejecución detenida, y en revisión. El Plan Maestro puesto en marcha y en plena operación (no sin grandes retrasos y dificultades de implementación) ha sido detenido en mayo del 2010 dados los cuestionamientos al proyecto respecto su estatus jurídico y al reflote de los argumentos respecto la necesidad de un aeropuerto de emergencia posterior al terremoto de febrero 2010. 
En esta comunicación se describe la propuesta "Ciudad del Viento", y se analiza algunas de las modificaciones que la propuesta original tuvo comparando ambas propuestas y evaluando críticamente los proyectos posteriores para el área en función de su coherencia con la propuesta original. Se evalúan en conjunto algunos aspectos de las bases de licitación de los concursos para dichos proyectos.

\section{1.- La propuesta original "Ciudad del Viento" como modelo de urbanización sostenible.}

La propuesta original para la urbanización del terreno del ex aeródromo Cerrillos, "Ciudad del Viento" (2001), está basada en la idea de una ciudad sustentable con carácter modélico, en tanto la intervención urbana estaba planteada para la conmemoración del Bicentenario de la república Chilena, en 2010.

El Concurso Internacional de Ideas Portal Bicentenario, buscó según sus bases:

"aprovechar la oportunidad de reconversión urbana que surge a partir del cierre del aeropuerto de Cerrillos (...) que por sus dimensiones y su localización permitirá desarrollar un proyecto de alto impacto en la ciudad. (...) y señalar una nueva manera de hacer ciudad, más acorde con los requisitos de nuestros tiempos, tanto desde la perspectiva de las necesidades urbanas en general, como la de los hogares y las personas, respondiendo en mejor forma a las crecientes exigencias de calidad de vida." (MINVU, 2001).

Este mandato, en conjunto con las indicaciones de las bases del concurso que se enuncian a continuación, marcaron el sello de la propuesta en tanto desde ellas se concluiría la necesidad de generar con la propuesta un modelo replicable o extrapolable a otras realidades urbanas, basado en generar una reflexión respecto la necesidades de una ciudad que se proyecta al futuro con 'calidad de vida' en una 'nueva manera de hacer ciudad', acorde a 'nuestros tiempos', concretando 'una forma nueva, creativa y segura de vivir la ciudad'. Son estos elementos, que llamaban a la innovación en la propuesta, los que llevaron al equipo ganador a fundar el diseño urbano basado en principios genéricos aplicables al desarrollo de cualquier conjunto urbano para generar un "modelo urbano".

Los criterios de diseño esperados según las bases del Concurso de Ideas y que permitirían "desarrollar un proyecto de alto impacto en la ciudad", eran (MINVU, 2001):

- Calidad de vida urbana, mediante un diseño urbano que considera factores ambientales, paisajísticos, arquitectónicos y de transporte que eleven la calidad 
de vida, valorándose contribuciones a concretar una forma nueva, creativa y segura de vivir la ciudad.

-Integración Territorial. Una propuesta que induzca al crecimiento equilibrado e integrado del tejido urbano y social existente y entre los diferentes subsectores físicos y componentes funcionales que conformen la propuesta, integración a nivel metropolitano y comunal.

-Optimización de la Conectividad. Las propuestas deberán proponer soluciones innovadoras que potencien la conectividad con el centro de la ciudad de Santiago y con las salidas hacia el sur y la costa. Asimismo deberán considerar una trama vial que conecte las comunas de Cerrillos con Pedro Aguirre Cerda y Lo Espejo incomunicadas por el aeropuerto, y considerar la proyección de extensión del Metrotren.

-Diversidad Funcional. Se espera que en las propuestas se plantee una diversidad funcional acorde con las expectativas de la vida urbana moderna.

-Gestión Pública con Inversión Privada. El Estado dotará al área de infraestructura básica y el sector privado realizará las mayores inversiones, creándose una entidad gestora mixta. Se espera que las propuestas de gestión partan de esta premisa, y que el diseño sea consecuente al modelo de gestión.

-Programación por Etapas y Flexibilidad del Desarrollo, en tanto se realizará en un horizonte de 15 años, considerando etapas consolidadas para septiembre de 2010. La propuesta deberá acoger los cambios en las tendencias del mercado.

Además de esos criterios, las bases consideraron un programa indicativo que contemplaba (MINVU, 2001):

-La incorporación de una cantidad aproximada de 15.000 viviendas para estratos medios, cuyos precios fluctuarán entre los 11 y 48 millones de pesos" considerando "variedad tipológica de la oferta residencial.

-Asociado a la vivienda se plantea considerar la incorporación de servicios de salud, establecimientos educacionales, instalaciones deportivas, centros de intercambio comercial y centros culturales tanto para los habitantes del Proyecto como para los vecinos de los sectores adyacentes.

-Se prevé la localización de la Residencia Presidencial y un Centro Cívico para la comuna de Cerrillos, el cual deberá contener al menos los edificios de la Municipalidad, Juzgado de Policía Local, Dirección de Tránsito, Registro Civil, etc.

-Se indica que se deberá mantener el edificio actual que contiene el museo aeronáutico. 
-Se considera otro equipamiento como opcional y se plantea la necesidad de estimular la presencia de actividades que generen empleo dentro del área de intervención, como actividades industriales no contaminantes, equipamiento de salud, centros culturales y deportivos a escala metropolitana.

Respecto espacios públicos y áreas verdes, las bases plantean que (MINVU, 2001): "El proyecto quiere dar una señal importante en dotación, diseño y mantención de los espacios de uso público". Se estableció "que al menos un tercio del terreno debe destinarse a espacios públicos incluyendo áreas verdes, parques y las vías", esto equivale a 82 há.

Bajo el mandato de las bases citadas y considerando el llamado que hizo el entonces presidente de la República Ricardo Lagos Escobar, en su discurso del 21 de mayo de ese 2001: "El País quiere llegar al Bicentenario con ciudades más bellas, menos contaminadas, más expeditas, dignas, amables y cultas", el equipo ganador se basó en elementos genéricos fundados en criterios de diseño capaces de ser replicados. Estos criterios se estructuraron bajo la idea de una "ciudad modelo" de innovación y bajo los conceptos de 'Sustentabilidad Urbana' y de 'Equidad Urbana'; ellos emergieron de la reflexión y crítica al modelo urbano de una ciudad polarizada socialmente, poco densa en población, contaminante y poco eficiente energéticamente como lo era el AMS, y con un importante déficit de áreas verdes y de servicios ecosistémicos: una ciudad considerada insustentable. Los fundamentos teóricos de dicha propuesta se encontraban en los trabajos sobre diseño ambientalmente sostenible y ecología urbana de M. Hough (1998), V. Betinni (1998), Ken Yeang (1995), Bentley, Alcock, Murrain, Mc Glynn y Smith (1999), J. Tood (1993), M. Ruano (1999), entre otros autores.

Según se indicó en las láminas de la propuesta original, el sentido último de la ""Ciudad del Viento"" es generar "Un modelo urbano integrado al medio ambiente, densa en población, con un alto porcentaje de áreas verdes, equipamientos y servicios". Se propone "transformar el lugar en un ejemplo de reciclaje de terrenos urbanos que articule a sus habitantes al medio natural y a los procesos de la ciudad como (eco)sistema" (González, R.; Ulloa, C., 2001). Para lo que se genera una urbanización mezclando "principios de sustentabilidad económica, ecológica, social y cultural, haciéndose cargo del reciclaje de la ciudad y en la ciudad", en suma, un modelo de urbanización (González R.; Ulloa C., 2001) que:

-Sea "densa en población, legible (en su morfología), multifuncional, heterogénea, compacta, eficiente, flexible, y dinámica (...), que aumente su biomasa y biodiversidad (...), que recicle sus propios desechos $(\ldots)$, que genere parte de la energía que consume (...), que minimice su impacto en el medio ambiente, y plantee al habitante un nuevo modo de vida, como parte de la naturaleza y sus procesos o ciclos." 
-"Donde la red de infraestructura permita a todos acceder al intercambio de materia, energía e información, y conectarse con los servicios, equipamientos, y espacios públicos desde cualquier punto del sistema."

- "Con espacios públicos integrados a los procesos ecológicos y sociales: Espacios públicos ciudadanos y espacios públicos productivo-ecológicos."

-Que "transforme el espacio público tradicionalmente yermo, en un espacio público productivo, útil, generador de empleo y con función ecológica. Un espacio público que entiende que la ciudad es territorio escaso, y que es terreno al que hay que sacarle el máximo provecho."

-Que posea "equipamientos para toda la comuna, y (...) que contenga un alto porcentaje de áreas verdes y zonas libres públicas, accesibles a todos (...), y una alta densidad poblacional que de vida urbana al conjunto".

-Que posibilite "un aumento en la calidad de vida y cultura, (...), fomente los procesos de participación y brinde posibilidades reales de un futuro deseable para los ciudadanos: esperanza".

Ese modelo urbano toma forma a través de diseño urbanístico que busca un cambio de paradigma de una ciudad o modelo urbanizatorio insustentable hacia una ciudad sustentable y se expresa en el modo de disponer la edificación, en el programa urbano, y en elementos simbólicos, funcionales y espaciales, que buscan reflejar el sentido de ese cambio. Se plantea una visión de ciudad futura respecto el AMS: "Un Santiago Sostenible, a ser construido en los próximos 100 años". En tanto, "la ciudad del siglo XXI debe ofrecer: futuro, calidad de vida, sustentabilidad ambiental, económica, social y cultural, equidad y participación a su población" (González, R.; Ulloa, C., 2001).

La propuesta busca responder a la principal crítica que esta iniciativa MINVU tiene desde el ámbito de la Geografía en 2001, al ser lanzado el concurso. Se trata del posible impacto ambiental que la propuesta tendría sobre la circulación local de viento y humedad relativa de Cerrillos, las comunas aledañas, y el centro de Santiago; sobretodo, considerando que con el proyecto se libera la restricción sobre el cono de aproximación al aeropuerto, que mantenía a los terrenos entre la avenida General Velásquez (actual carretera Autopista Central) y la Av. Pedro Aguirre Cerda y Camino a Melipilla y su proyección al sur, en una situación semi-rural (morfológicamente periurbana).

Este cono implica el desarrollo y transformación gradual y progresiva a usos urbanos de los terrenos desde el Aeropuerto, hasta el añillo Américo Vespucio, y hasta los Cerros Chena proceso ya en pleno desarrollo. Como muestran las imágenes 02, 03, 04 y 05 , esta discusión es aún un tema vigente y relevante, no resuelto por los sistemas de declaración de impacto ambiental implementados en el proceso de desarrollo del proyecto. Romero y Vásquez analizan en 2005 "los efectos de la urbanización sobre indicadores ambientales críticos en una urbanización de características parecidas (al terreno del ex aeródromo Cerrillos), que ha tenido lugar en un triángulo espacial ubicado en la Comuna de Maipú, al sur de la Carretera 68". Usando imágenes 
satelitales y "comparando la situación de las temperaturas superficiales, la humedad del suelo, la biomasa y la productividad vegetal que existían en 1989 y lo sucedido en 2003, concluyen que las transformaciones urbanas ocurridas en Maipú han sido adversas para la salud ambiental de la ciudad, y que no difieren de los efectos negativos causados por la urbanización reciente en los bordes de toda la ciudad, que han implicado enormes pérdidas en los servicios ambientales de la cuenca de Santiago" (Romero, H.; Vásquez, A., 2005).

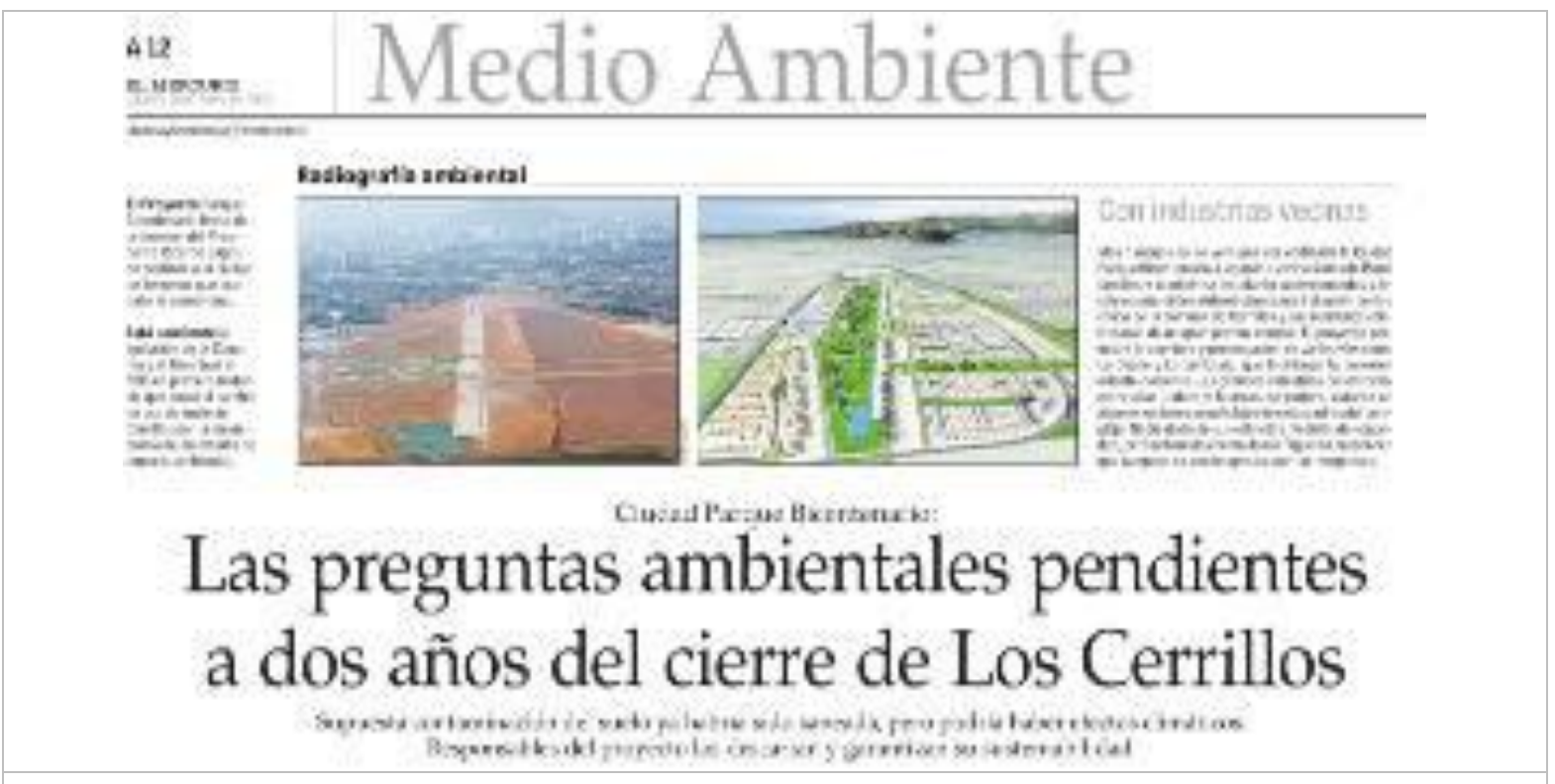

Fig.2.- El Debate en la prensa sobre los posibles impactos de la Urbanización del terreno del Aeropuerto Cerrillos.

Sección Medio Ambiente Diario El Mercurio. Viernes 18 Abril. 2008. 
Para Romero y Vásquez "el Portal Bicentenario de Cerrillos constituye una invitación para urbanizar una de las pocas áreas en las cuales la mancha urbana no se había extendido hacia la periferia en forma continua (...) en un área que había mantenido coberturas superficiales y usos del suelo correspondientes a áreas agrícolas, con remanentes de vegetación natural". Explican que la geometría del "cono de aproximación al Aeropuerto de Cerrillos está orientada de SW a NE y se acopla con los vientos regionales". Argumentan que el cono es un efectivo corredor de ventilación que puede ser gravemente alterado por la transformación de los usos del suelo, pasando de ser un eje de ventilación, a un eje de contaminación, y privar a la ciudad de uno de las pocas fuentes de aire limpio, necesarias para mitigar los efectos de su saturación por contaminantes atmosféricos". Para los autores, el dilema más importante generado por el proyecto consiste en "evitar los efectos ambientales adversos que resultan de urbanizar un área que no estaba afectada por el crecimiento de la ciudad" (Romero, H.; Vásquez, A., 2005).

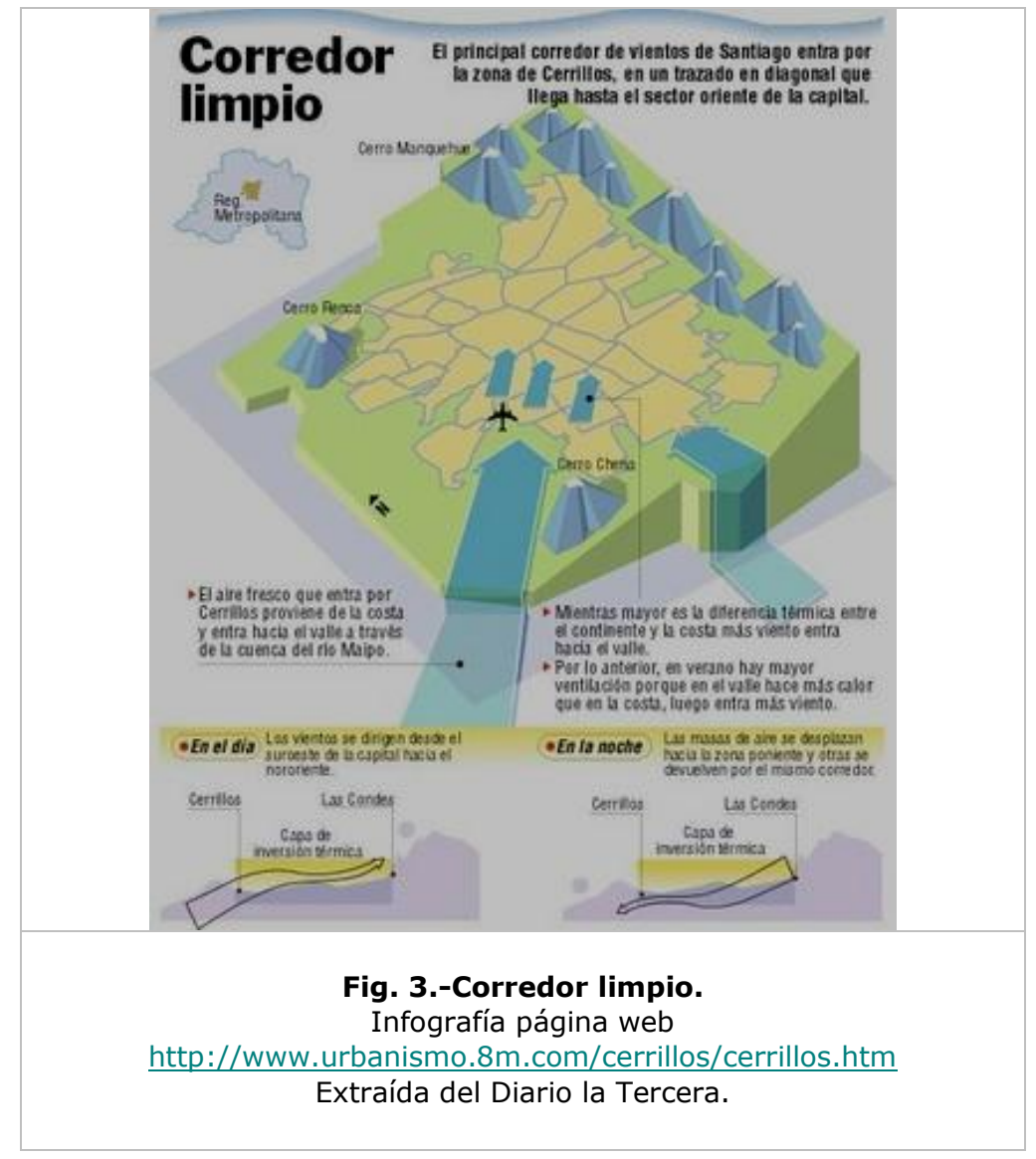




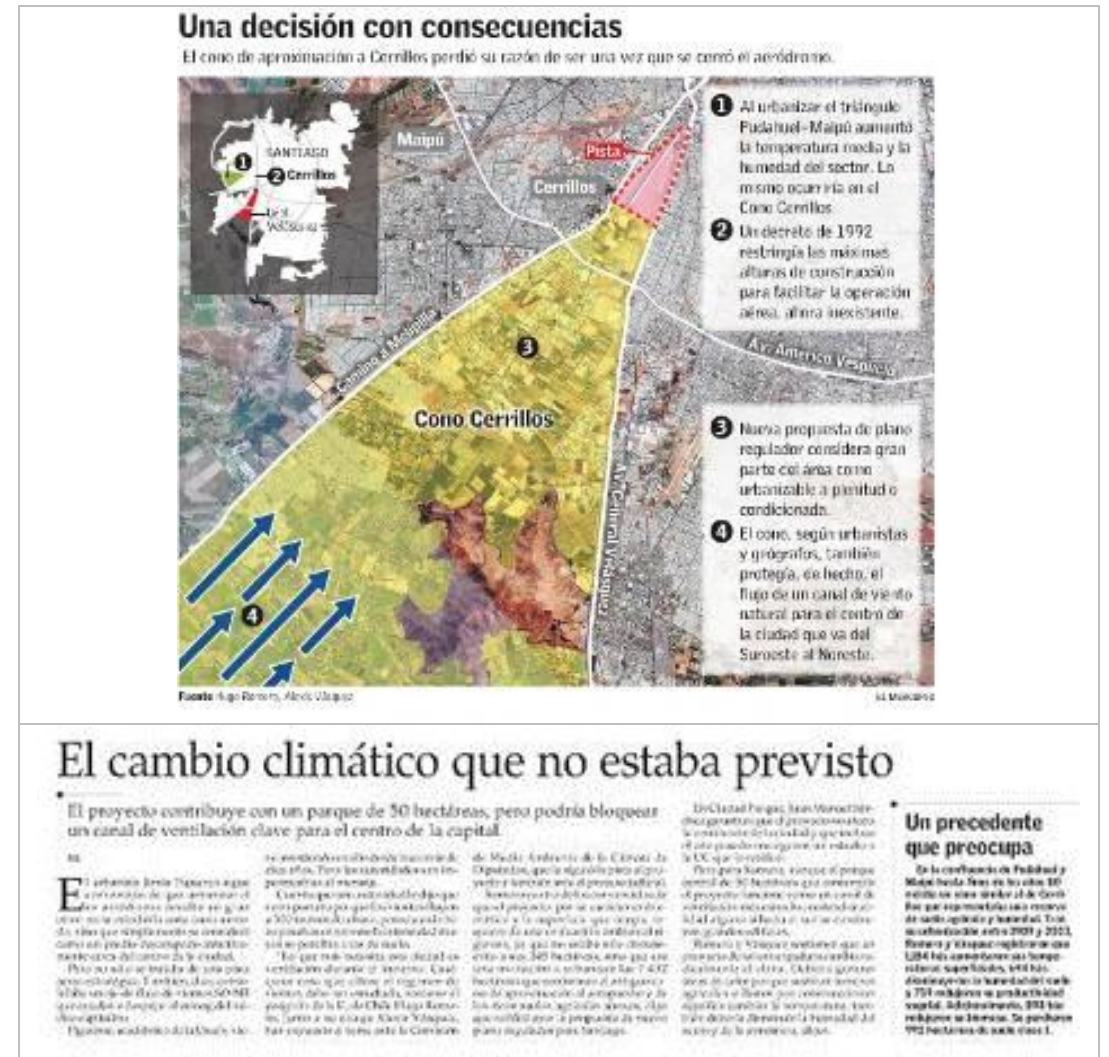

Figs. 4.- y 5.- Una decisión con consecuencias. El cambio climático que no estaba previsto.

Zoom sección Medio Ambiente Diario El Mercurio. Viernes 18 Abril. 2008.

Romero y Vásquez (2005), quienes comienzan a aportar datos empíricos desde una investigación científica estructurada comparativamente con casos de similares características al de Cerrillos, señalan tres posibles posiciones respecto del manejo del área, por la autoridad pública:

-los antecedentes no justifican las transformaciones propuestas;

- Ios planes para las áreas urbanas reconocen la posición estratégica de esta área, y proponen mantener sus usos actuales del suelo y fortalecer las funciones y servicios ambientales significativos que presta como consecuencia de conservar los suelos agrícolas y paisajes naturales; 
- Ios planes de urbanización, reconociendo la sensibilidad ambiental del área, consideran explícitamente la planificación ambiental del proyecto en su formulación estratégica, diseño y evaluación de impactos (Romero, H.; Vásquez, A. 2005).

Es justamente la última opción citada la que habría sido considerada en el diseño original de la propuesta de 2001, reconociendo este posible impacto de la iniciativa MINVU, como el aspecto que debiese haber sido la principal característica de la urbanización: una acción preventiva mitigadora del impacto ambiental y generadora de acciones de remediación ambiental, mediante una urbanización sostenible.

En las palabras del texto que acompañaba la propuesta original ganadora:

"Se propone, un nuevo trozo de ciudad que reconoce la condición del sitio como una entrada de vientos (locales) a la cuenca de Santiago (...). Para eso reformulamos: el concepto de infraestructura urbana, el concepto de espacio público, y el modo de entender los procesos biológicos y ecológicos en la ciudad. La llamamos: 'CIUDAD DEL VIENTO'." (González, R., Ulloa, C., 2001).

Los objetivos antes declarados se sintetizan en una idea que representa el cambio hacia la ciudad sostenible y se simboliza a través de un molino de viento, el que representa, a la vez, las condiciones propias del terreno y del uso preexistente como aeropuerto. La imagen del aerogenerador es tanto un símbolo de las hélices de los aviones así como del cambio hacia la ciudad sostenible. Incorporando la crítica sobre el impacto ambiental de la propuesta a la estrategia del proyecto para reconceptuar el uso urbano y generar un modelo de urbanización moderado, sostenible, que libera más del $50 \%$ del total del paño urbano como áreas verdes. Estas ideas se evidencian en la forma urbana propuesta.

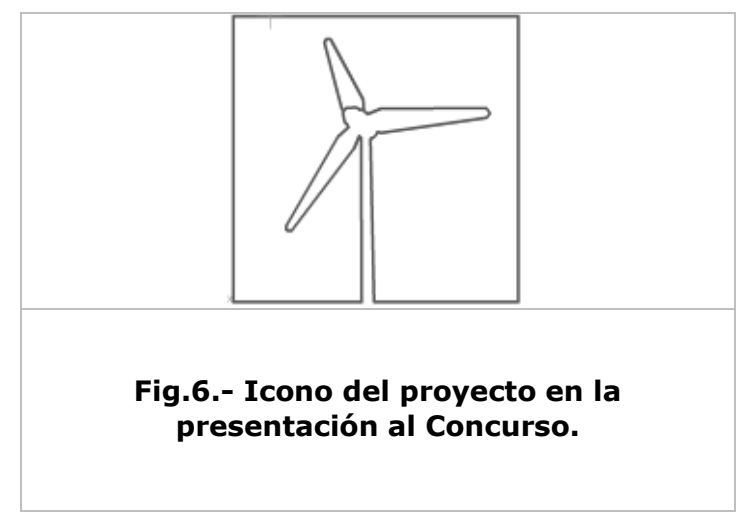




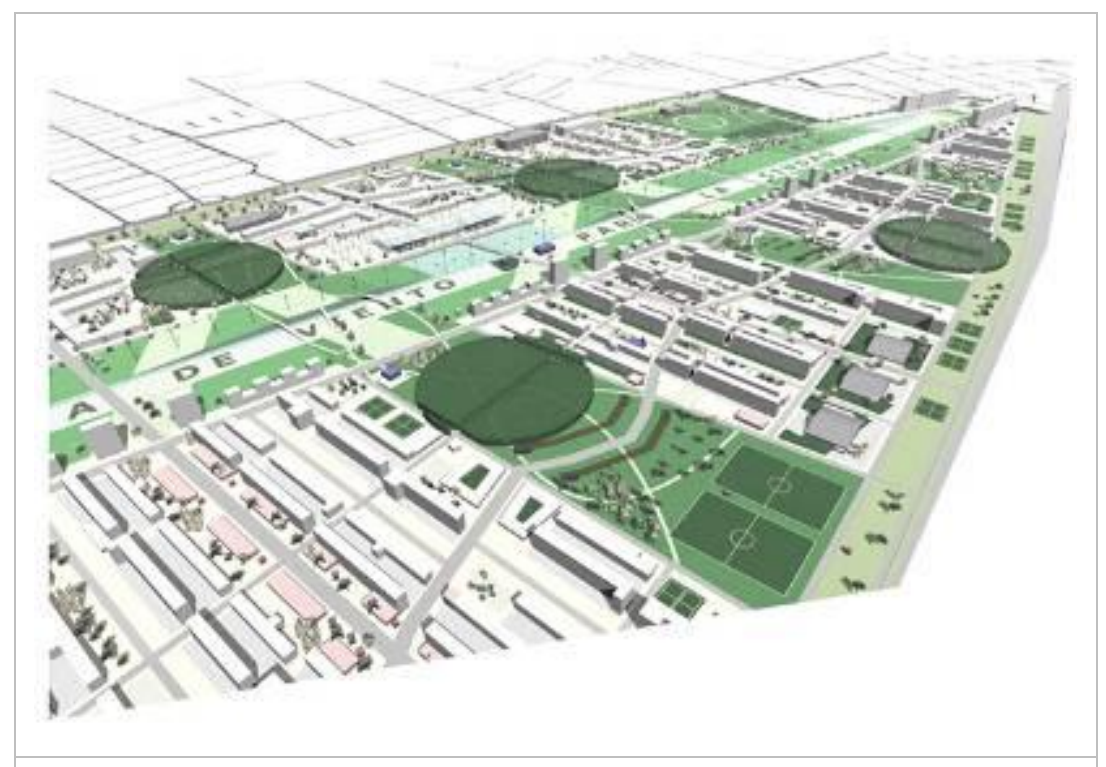

Fig.7.- Perspectiva "Ciudad del Viento" Cerrillos.

Elaboración González, R.; Ulloa, C.; 2001, documentos presentados Concurso Ideas Portal Bicentenario.

La "Ciudad del Viento" resulta ser un símbolo modélico y metafórico de la necesaria vinculación de la ciudad a los sistemas que le dan soporte ambiental. Los molinos son una referencia a las aeronaves como parte del proceso de reciclaje de la ciudad, son una referencia de los procesos de eficiencia energética (cuestión en la que se ha centrado el debate chileno a nivel político en torno a la sustentabilidad de la edificación hasta hoy) y una referencia a la reducción del impacto ambiental y al cambio tecnológico.

La estructura que se propone para el conjunto intenta vincular la urbanización con las unidades ambientales que se encuentran al sur del terreno mediante un corredor ambiental de $300 \mathrm{mt}$. de ancho, proyectado desde la cabecera norte del terreno hasta los cerros de Chena. Este corredor ayudaría a mantener la temperatura de la masa urbana baja, con un adecuado modelo de urbanización sustentable. Se plantea para ello un parque central dispuesto en el sentido de los vientos predominantes, se recomienda su continuidad al sur, se disponen parques transversales de un ancho promedio similar y se diseñan estrategias de minimización del caldeamiento de la masa urbana, así como la incorporación de espacios naturalizados como zonas de 
arborización densa y la anexión de vegetación y fauna mediante programas urbanos específicos, y alternativas de humidificación del área.

También se establecen criterios respecto de la distribución de superficies y programa urbano de ""Ciudad del Viento"". El proyecto se basó "en la distribución equitativa del programa respecto a una red de infraestructuras básicas (de comunicación y conectividad)", esta "repartición y variedad del programa, asegura una mezcla adecuada de usos, y circuitos de recorrido peatonal comercialmente atractivos, fomenta la complementariedad en las actividades y posibilita la generación de economías y riqueza en la vida urbana del conjunto" (González; Ulloa, 2001).

Se distribuye al centro un parque productivo - ecológico con parques que penetran a los barrios tanto al oriente como al poniente de este; al oriente los barrios son fundamentalmente residenciales con programa social, educacional y comercio menor, concebidos como barrios solares en torno a parques; y al poniente, barrios residenciales con industria inofensiva de escala pequeña, comercio y programa urbano de equipamiento y servicios de carácter intercomunal y metropolitano, sector al que se llamó parque de actividades" (González, R.; Ulloa, C. , 2001).

Como resultado, queda despejada más de la mitad de la superficie total del polígono destinada a parques y áreas públicas (130há de parques), preservando la condición medioambiental del terreno como entrada de vientos bajos. Estos parques, constituyen "un territorio transformado en un espacio público útil y simbólico, cuyo objetivo es hacer evidentes los procesos ecológico-urbanos que contiene. Una 'ecología artificial' cuyo objetivo es minimizar el impacto del proyecto sobre la ciudad" (González, R.; Ulloa, C., 2001). 


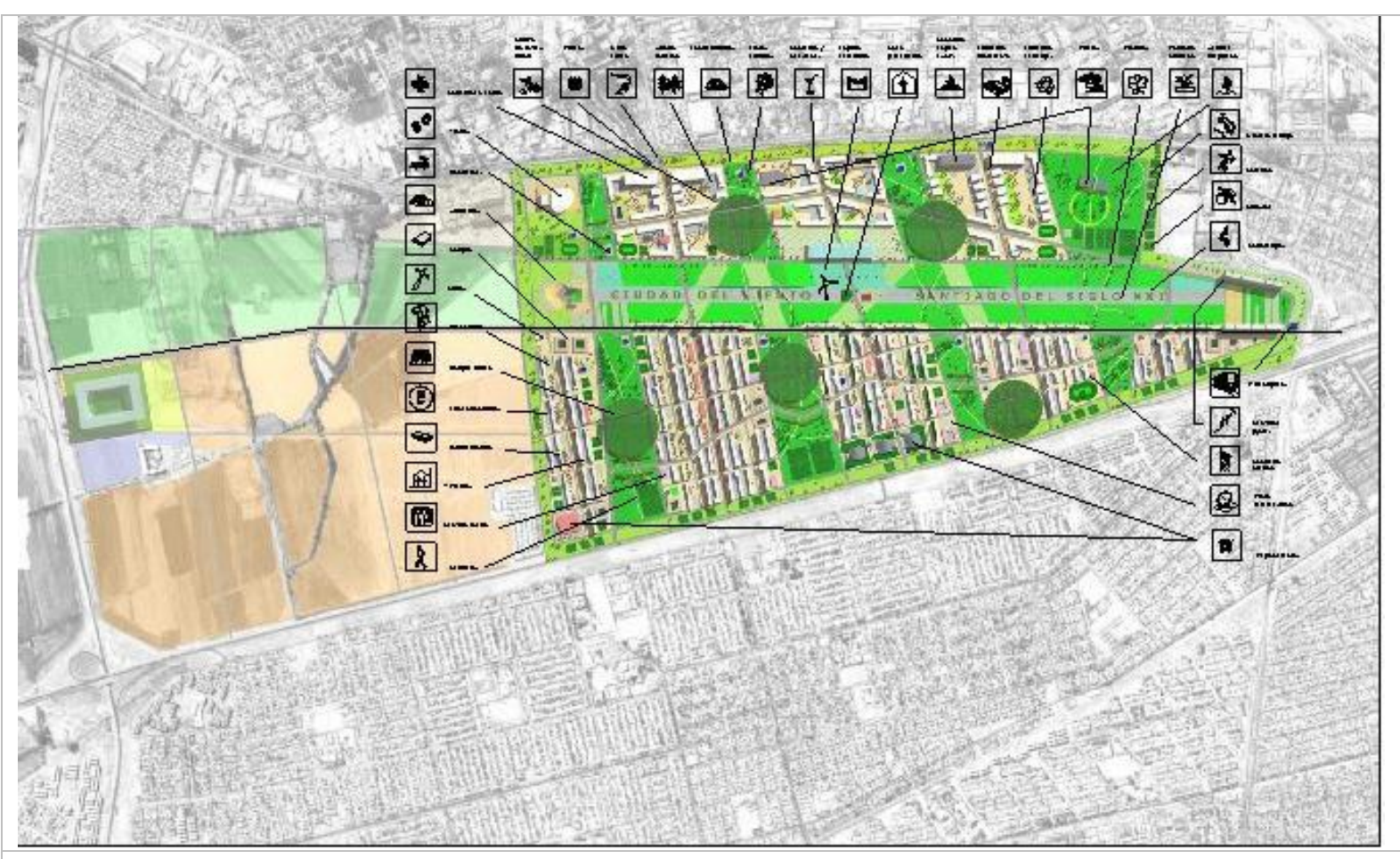

Fig.8.- Planta "Ciudad del Viento" con ubicación del programa urbano.

El norte se ubica a la derecha de la imagen.

Elaboración González, R.; Ulloa, C.; 2001, documentos presentados Concurso Ideas Portal Bicentenario.

Para la configuración de dicha "ecología artificial urbana" se instaura una articulación programática vinculante con los procesos de metabolismo urbano tipo circular (procesos de reutilización, reciclaje, fitorremediación y biodegradación, incorporados en los flujos o cadenas de procesos urbanos), que se muestra en la imagen 9. Este programa se concibe incorporado al espacio público a los barrios y entornos construidos, como muestra la Fig.-10, ello para posibilitar un vínculo activo y pedagógico que posibilite la reproducción de conductas sostenibles entre los habitantes del conjunto: la ciudad sustentable es también una ciudad pedagógica respecto de la sustentabilidad.

Para ello se disponen en el espacio público programas de reciclaje de aguas con la forma de silos solares, invernaderos conocidos como Living Machines, sistemas de lombricultura conocidos como sistema Toha, pantanos artificiales, reed beds, se disponen también "lagunas artificiales de acumulación y absorción que recorren lateralmente la pista, y permiten el riego de los espacios públicos en verano (...) ellas 
evitan acumulación de agua en otros terrenos en invierno e integran al conjunto al ciclo hidrológico de la ciudad", (González, R.; Ulloa, C., 2001) además de humidificar el entorno y contribuir a dar inercia térmica a la masa urbana disminuyendo corrientes convectivas que perturben el flujo de vientos. Se sitúan programas orientados al reciclaje de desechos orgánicos como áreas de arborización densa, floricultura, lombricultura, estaciones de biodiversidad, entre otros.

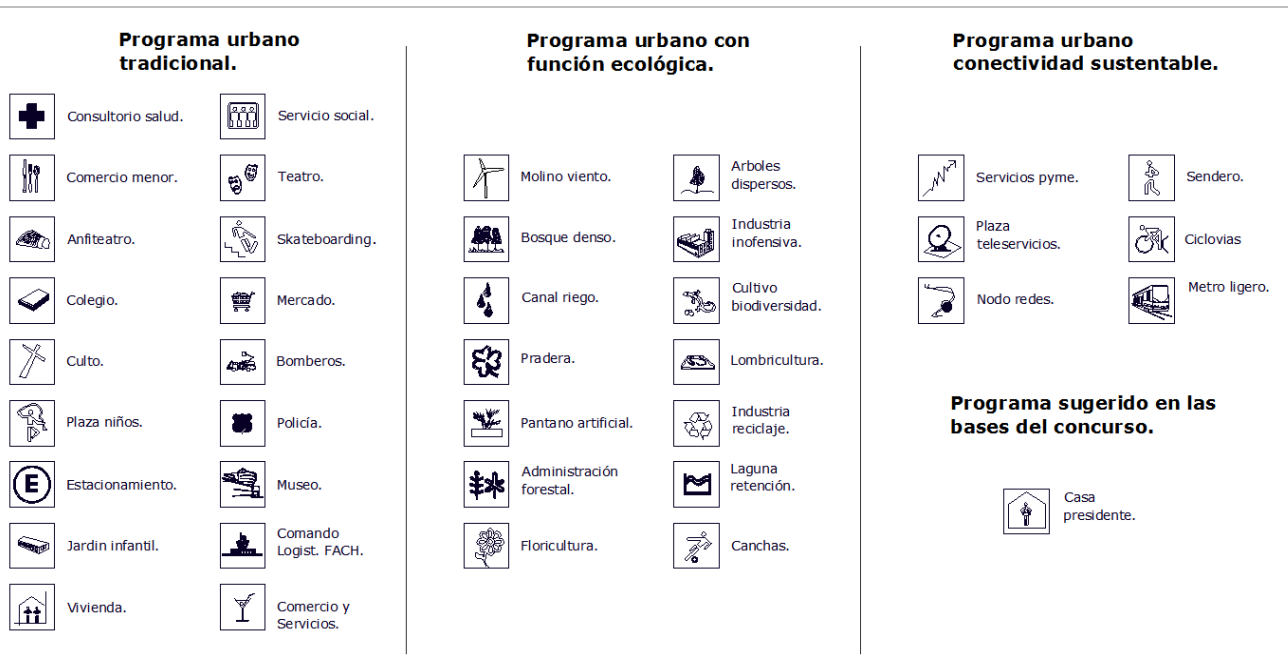

Fig.9.- Conceptualización Ecología artificial "Ciudad del Viento". Espacios y programa urbano. Elaboración González, R.; Ulloa, C.; 2001, documentos presentados Concurso Ideas Portal Bicentenario. 
Se trata de dotar a los espacios públicos parque de una función y sentido ecológico, y, a la vez, de una función energética para el conjunto, en palabras del texto presentado al concurso: "el parque genera energía eólica a través de molinos de viento y termina con el proceso de reciclado del agua servida del sector habitacional del conjunto" (...); este espacio público con carácter productivo ecológico "no pretende auto-sostener a todo el conjunto, sino satisfacer parte de las necesidades generadas por él" (González, R.; Ulloa, C. , 2001). Se trata sobre todo de un espacio que muestra el funcionamiento del modelo de sinergia urbana que se plantea.

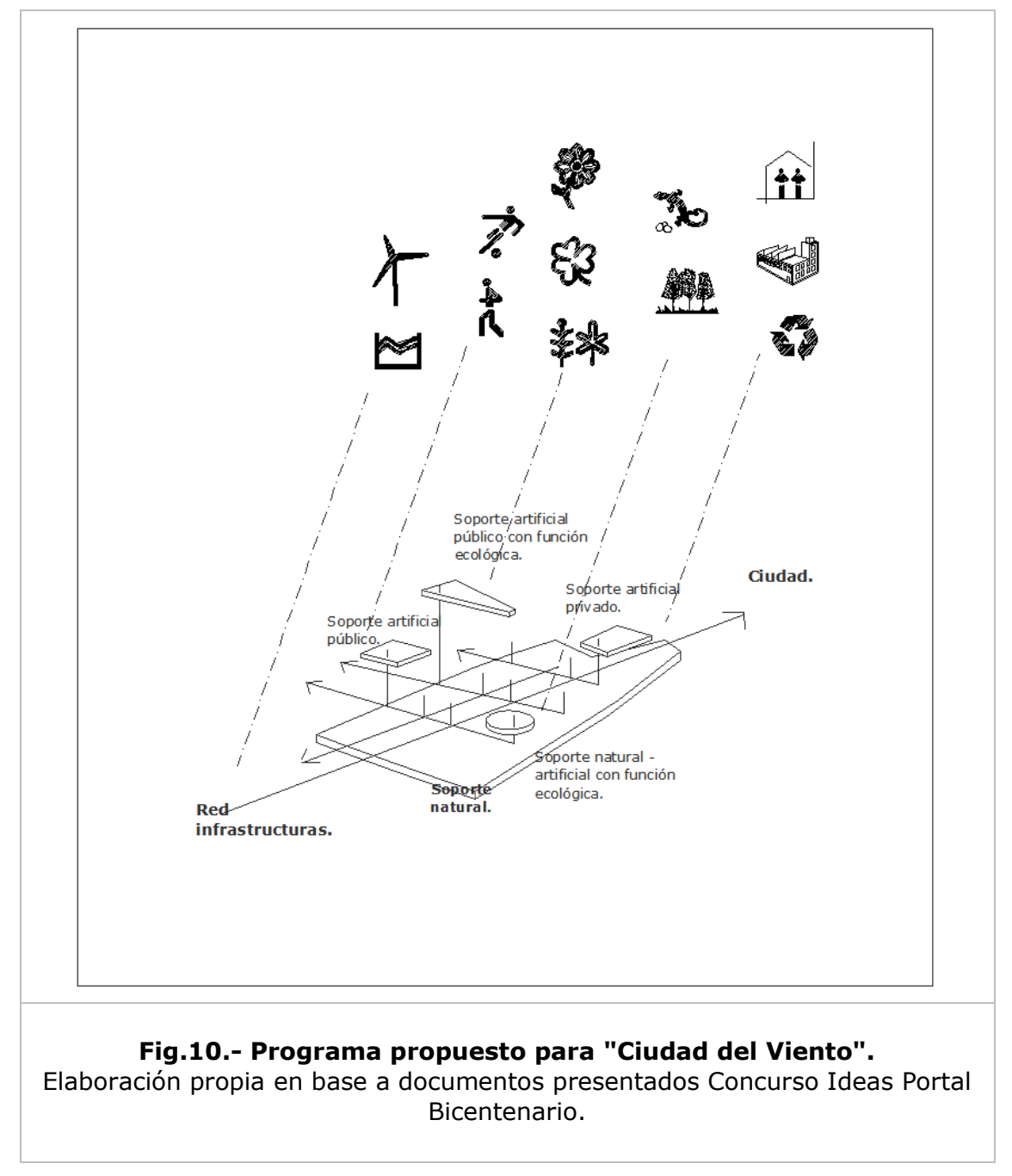


En la propuesta este ecosistema artificial dispuesto en el espacio público equivalente a los parques transversales y parque central toma un carácter especial en la pista; "a lo largo de toda su extensión, franjas de intervenciones paisajísticas alteran la imagen original de la antigua pista de aterrizaje (...). Pasto, cubiertas de maleza, zonas de grava, arena, componen esta zona naturalizada, dando espacio para que una gran variedad de especies de plantas, e insectos, reduzcan los desechos orgánicos generados por los habitantes del conjunto, en un real ejemplo del incremento de la biomasa y biodiversidad en la ciudad (...). Pantanos artificiales y silos solares de reciclaje de agua, se posan y perforan la pista formando las letras de un texto para ser leído desde el aire, que nos recuerda la memoria de este espacio y entrega un mensaje a las futuras generaciones. Ellas finalizan un proceso de purificación del agua en el espacio público y la entregan a la laguna artificial"(...) "Masas compactas de árboles, de forma circular que absorben agua lluvia, agua reciclada, y reducen residuos orgánicos producidos por los barrios", se disponen asociados a los barrios. Estas zonas de arborización densa constituyen una alternativa de recreo y una "muestra de una espacialidad diferente en el espacio público". (González; Ulloa, 2001). Estos posibilitan un programa de manejo silvicultural urbano y dado que están distribuidos de modo equitativo en el terreno, aseguran a los ciudadanos contacto con una forma urbana vinculada de una manera renovada con la naturaleza. Para ello "se alternan diferentes tipos de senderos que atraviesan la franja central, uniendo los recorridos de los parques y penetrando en las zonas edificadas, uniendo simbólica y visualmente los bosques densos de árboles" (González, R. ; Ulloa, C., 2001).
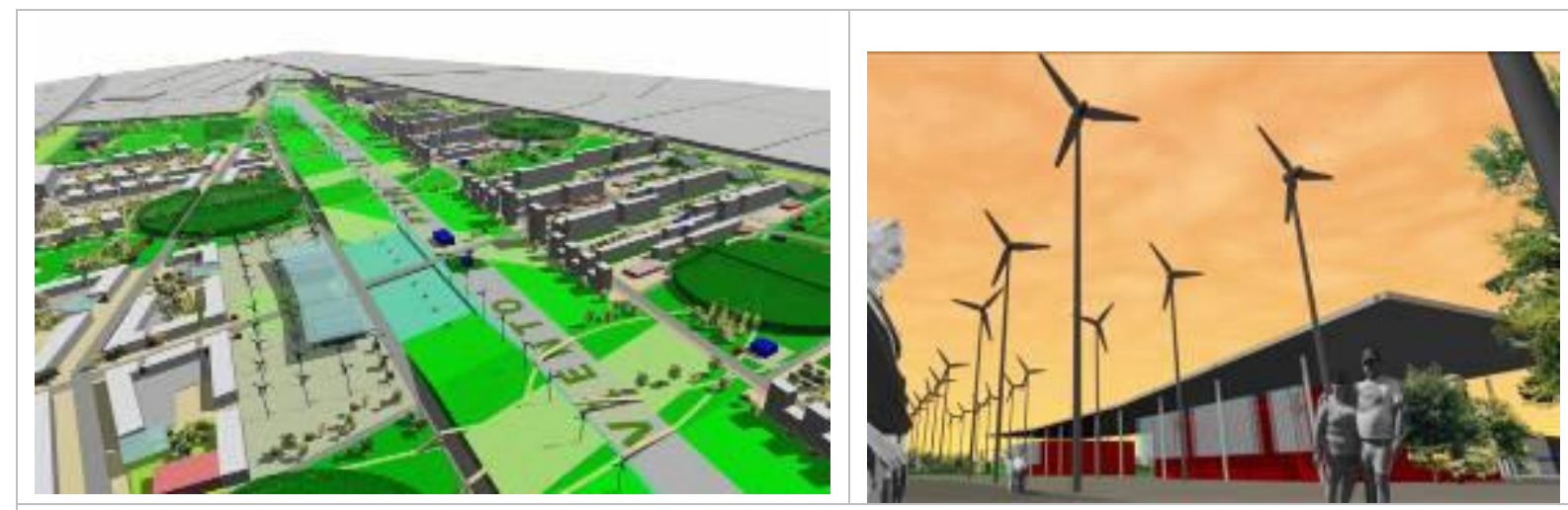

Figs.11.- y 12.-: Perspectivas "Ciudad del Viento" Cerrillos Sector Centro Cívico. Vista aérea y perspectiva Plaza de Los Molinos.

Elaboración González R.; Ulloa C.; 2001, documentos presentados Concurso Ideas Portal Bicentenario.

En las zonas de parque, este programa sumado a "las distintas actividades de reproducción de la biodiversidad, hacen del conjunto un verdadero un parque 
biotecnológico (...). Un programa de mini zoológicos, industrias de reciclaje, zonas de cultivo intensivo forestal-hortícola, floricultura, etc., preservan la vegetación original, incorporando vegetación nativa, y reciclan parte de los desechos generados por la zona empresarial e industrial." (González R.; Ulloa C., 2001). El parque es, por tanto, concebido como una máquina metabólica para la urbanización bajo el concepto de espacio público productivo.

El parque, además de contener repartida en toda su superficie el programa ecológico, dispone de "un programa especial en sus dos extremos y en su centro, donde la laguna artificial de acumulación termina y se ensancha respectivamente. Al sur, la Plaza de los Sonidos, un anfiteatro metropolitano y pipas de viento se levantan en la zona de encuentro con el agua, espacio para la música y para las artes. Al norte la Plaza de las Banderas, el patio de dos edificios que delimitan el extremo del proyecto hacia la Av. Departamental, conteniendo centros de capacitación y un centro de Pymes, es el espacio del fomento a la creatividad y emprendimiento. En el centro, donde la laguna toma su máximo ancho, y el viento, es acelerado por el efecto de la superficie de agua, se plantea la Plaza de los Molinos, el lugar más representativo del potencial ecológico de la propuesta, (...) un espacio público - cívico masivo nuevo para la comuna, con el edificio consistorial, paralelo al parque ecológico y rodeado por dos zonas de bosques densos en sus extremos norte y sur; este es símbolo del cambio tecnopolítico para la sustentabilidad. Al oriente de esta plaza, la casa del Presidente de la República y el edificio del Auditorio Civil, un lugar de conferencias y actos públicos" (González; Ulloa, 2001). Estos programas contienen asociaciones simbólicas con el viento, como forma de mostrar la incorporación de la remediación ambiental al proyecto y complementan la lógica de sinergia entre sistema político de administración de la ciudad, las instancias de reunión masiva de la población, las posibilidades de nuevas economías asociadas al nuevo programa urbano y el metabolismo circular urbano que se propicia.

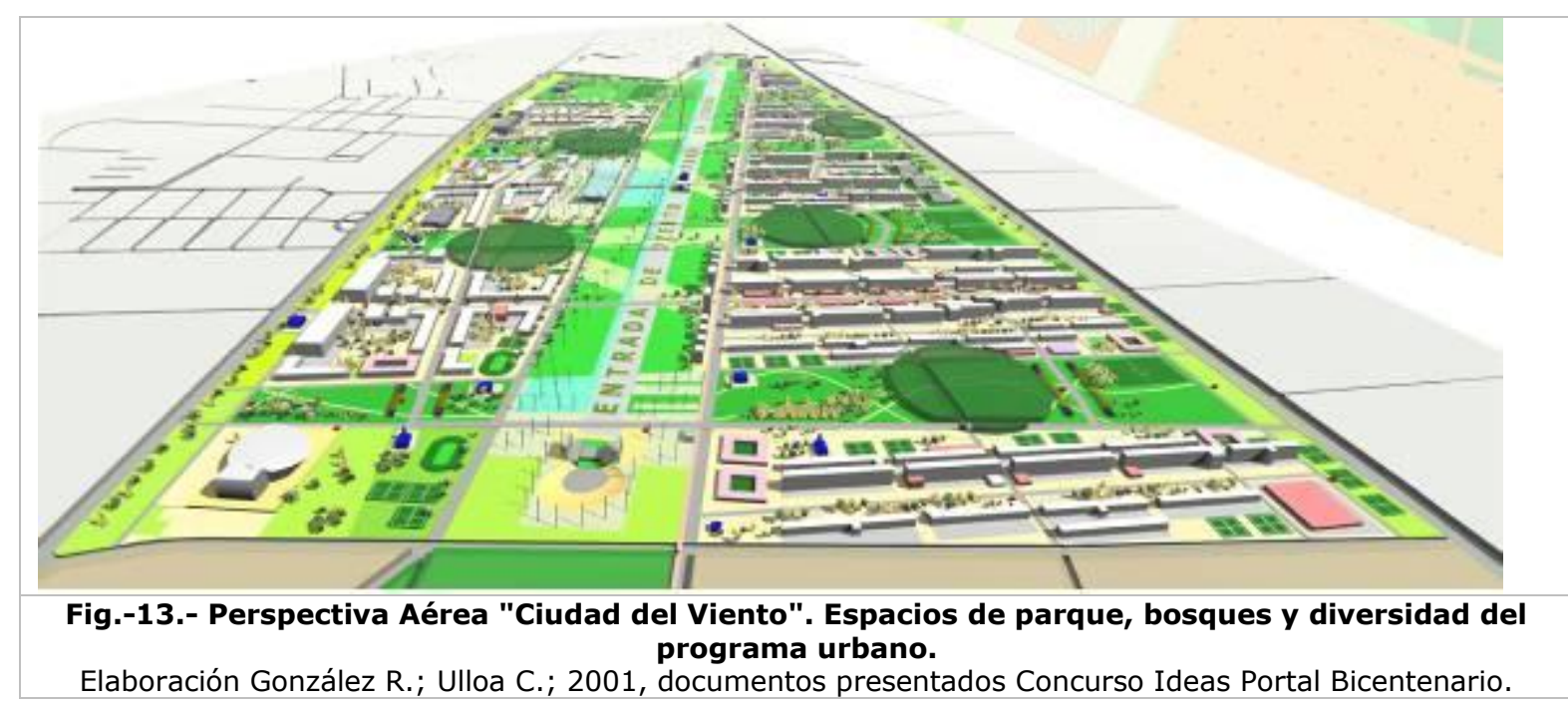


Por otra parte los barrios, concordante con lo planteado al enunciar el proyecto, son una solución densa en población y con mixtura de usos de suelo, conteniendo actividades diferentes, distribuidas de acuerdo a la oferta urbana de cada sector. La estructura vial y de servicios del proyecto se encuentra conectada con la trama urbana existente. Estos barrios permiten una alta concentración de población (sobre 300 hab/há) fomentando el crecimiento hacia el interior de la ciudad. Ellos se alternan en un continuo verde, que mantiene baja la temperatura media de la zona, para evitar la formación de una isla térmica que desvíe el paso del viento (González R.; Ulloa C., 2001).

La edificación se dispone en grupos de naves paralelas, orientadas predominantemente al norte, para captar energía solar. Las zonas de estacionamientos se disponen en la fachada sur, aprovechan la sombra de las construcciones para minimizar su caldeamiento (disminuyendo la superficie de pavimento expuesta al sol). Las alturas de edificación aseguran un mínimo de 4 horas de luz solar directa el día más corto del año, según lo posibilitan los distintos anchos de calles, y distanciamientos" (...). "Se propone una volumetría dinámica, basada en una nave de crujía $10 \mathrm{~m}$ de ancho, que se altera cuando contiene equipamiento o servicios, y en su altura, para generar espacios de iluminación extra y terrazas comunes que relacionarán visualmente la vida en los edificios con las actividades del parque. Como resultado se obtiene un conjunto diverso, con grandes posibilidades arquitectónicas para cada unidad. El primer piso de las naves concentrará un mayor número de departamentos con anchos de crujía pequeños, asegurando la mayor cantidad posible de puertas a la calle, a ambos lados de la nave, potenciando al máximo la seguridad, uso y cuidado de los espacios públicos." (González, R.; Ulloa, C., 2001). 


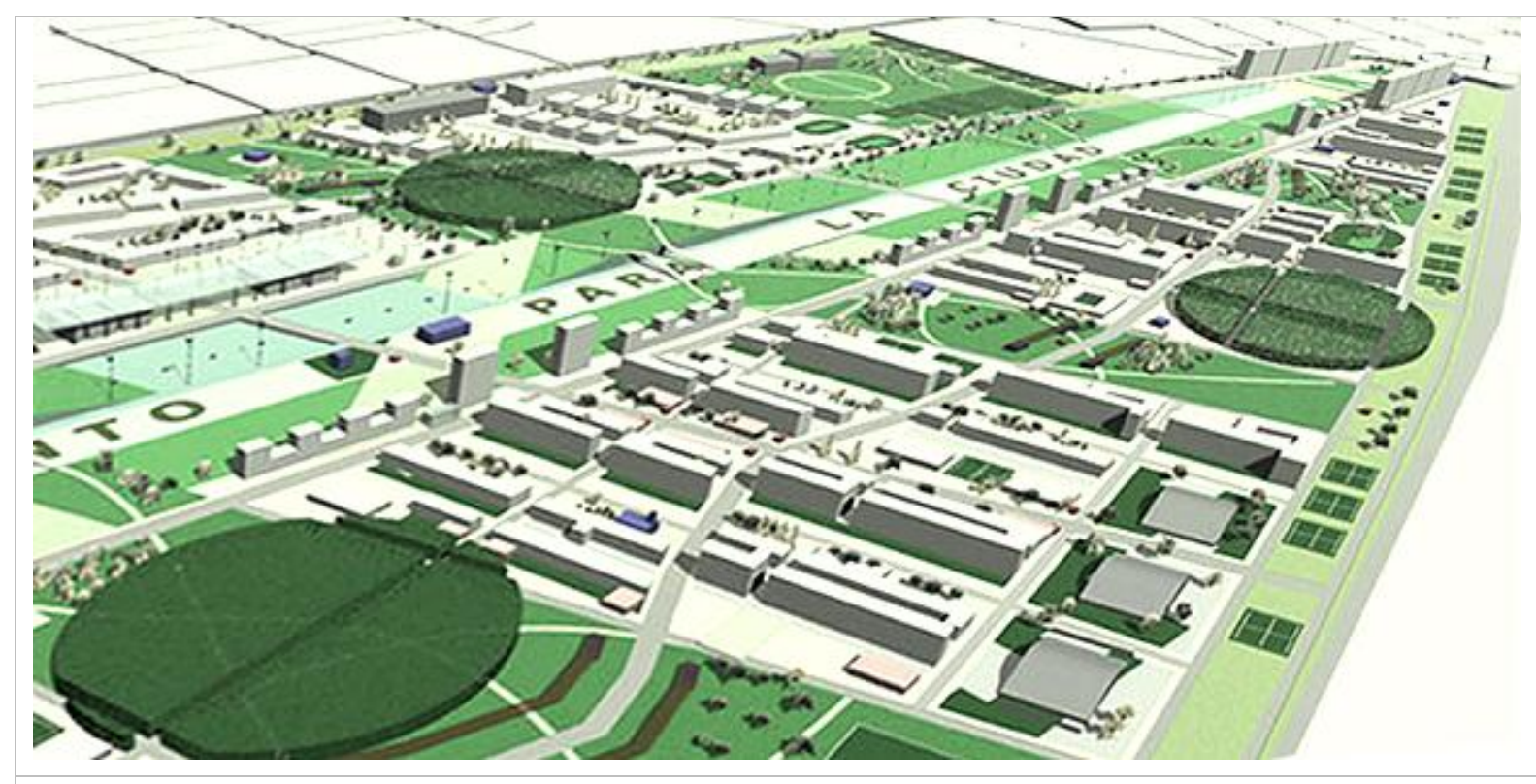

Fig.-14.- Perspectiva aérea de los barrios en "Ciudad del Viento".

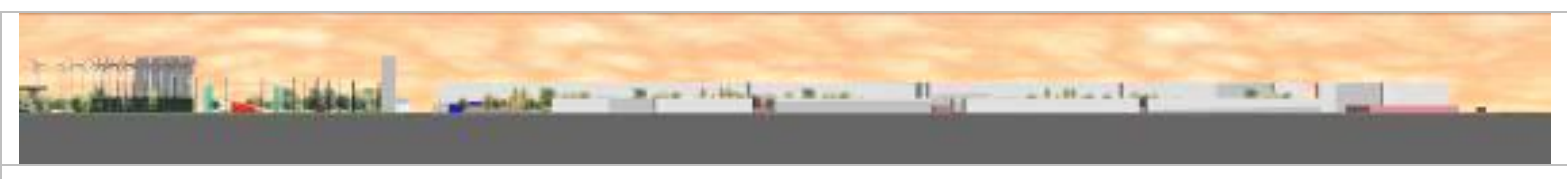

Fig.-15.- Sección de elevación norte de volumetrías en un barrio solar en "Ciudad del Viento". Elaboración por González R.; Ulloa C.; 2001, documentos presentados Concurso Ideas Portal Bicentenario.

Los barrios "estarán equipados con todos los servicios necesarios (...) cada uno comunicado con su entorno por una avenida central oriente-poniente, donde se ubica el comercio, y por un parque peatonal que concentra en torno suyo al equipamiento (...). Cada barrio deberá atender a distintos grupos socioeconómicos y a distintos agentes interesados en el sector, diversificando la oferta de construcciones. Equipamiento públicos y servicios privados, se mezclan con vivienda, colegios, jardines infantiles, locales comerciales, hogares estudiantiles, etc." Diversificar el programa permite "fomentar la vida y el intercambio en el espacio público, dándoles vida y seguridad (...) evitando zonas exclusivamente comerciales, que queden abandonadas durante la noche, además de posibilitar el máximo de fuentes de empleo 
generadas en el mismo conjunto y cuidado de los espacios públicos" (González; Ulloa, 2001).

"El comercio a mediana escala y los servicios en los barrios se encuentran en las vías centrales de los barrios con los mayores flujos del conjunto" y conectados con los barrios del entorno. Están ubicados en las primeras plantas de los edificios, dispuestos fundamentalmente en las equinas, $y$ distribuidos homogéneamente. (...) El equipamiento, se concentra en torno a las avenidas más importantes $y$ en torno a los parques: establecimientos educacionales públicos y privados, centros sociales, recreativos y juveniles, equipamiento deportivo, canchas, club deportivos, iglesias, tenencias y puntos de conexión a las redes de infraestructura se disponen de modo equitativo asociado a los barrios" (González, R.; Ulloa, C., 2001).

Respecto a la estructura vial del conjunto (ver imagen 16), esta se estructura en torno a "dos avenidas paralelas, y una línea de metro ligero que rodean al parque ecológico central y conectan al conjunto con la urbe en sentido norte-sur. Estas avenidas concentran la imagen más potente de la nueva ciudad, mostrando todos los sectores del conjunto." Casi perpendiculares a estas "las calles principales de los barrios, de oriente a poniente, son las de traspaso" hacia el entorno inmediato de la propuesta. "Un circuito interior da vida y unifica los recorridos (...) una avenida con una ciclovía que concentra en torno así los establecimientos educacionales en los barrios, la Avenida de los Colegios. (...) Un parque perimetral de borde y una calle caletera amortiguan el impacto de las grandes vías que rodean al predio" (González, R.; Ulloa, C., 2001).

Al describir el modelo de gestión solicitado en las bases del concurso, se indica que son "cuatro los principios básicos que pretenden generar sustentabilidad en la propuesta: gestión ecológica, económica, social y cultural, ello mediante un fuerte compromiso del sector privado, y con el Estado como gestor, guía y fiscalizador de los procesos de construcción y desarrollo del conjunto", al tiempo que el sector privado participa de la oferta de servicios ecológicos, operará áreas concesionadas de los espacios públicos productivos de libre acceso a los ciudadanos y desarrollando faenas de producción ecológico-urbanas.

Este modelo aseguraría la disminución de la huella ecológica de la ciudad, unificando esfuerzos público-privados y destinando "espacio público al servicio de los procesos ecológicos de la urbe para obtener: agua reciclada para riego; un aumento de la biodiversidad; disminución de los viajes al interior del conjunto; disminución del riesgo de inundaciones; energía producida sin impacto ambiental; basura orgánica reciclada", un entorno urbano vivo y, además, un "mejoramiento de la imagen de la comuna y de la ciudad, al ser el primer proyecto piloto de un medio ambiente urbano sostenible"(González, R.; Ulloa, C., 2001). 


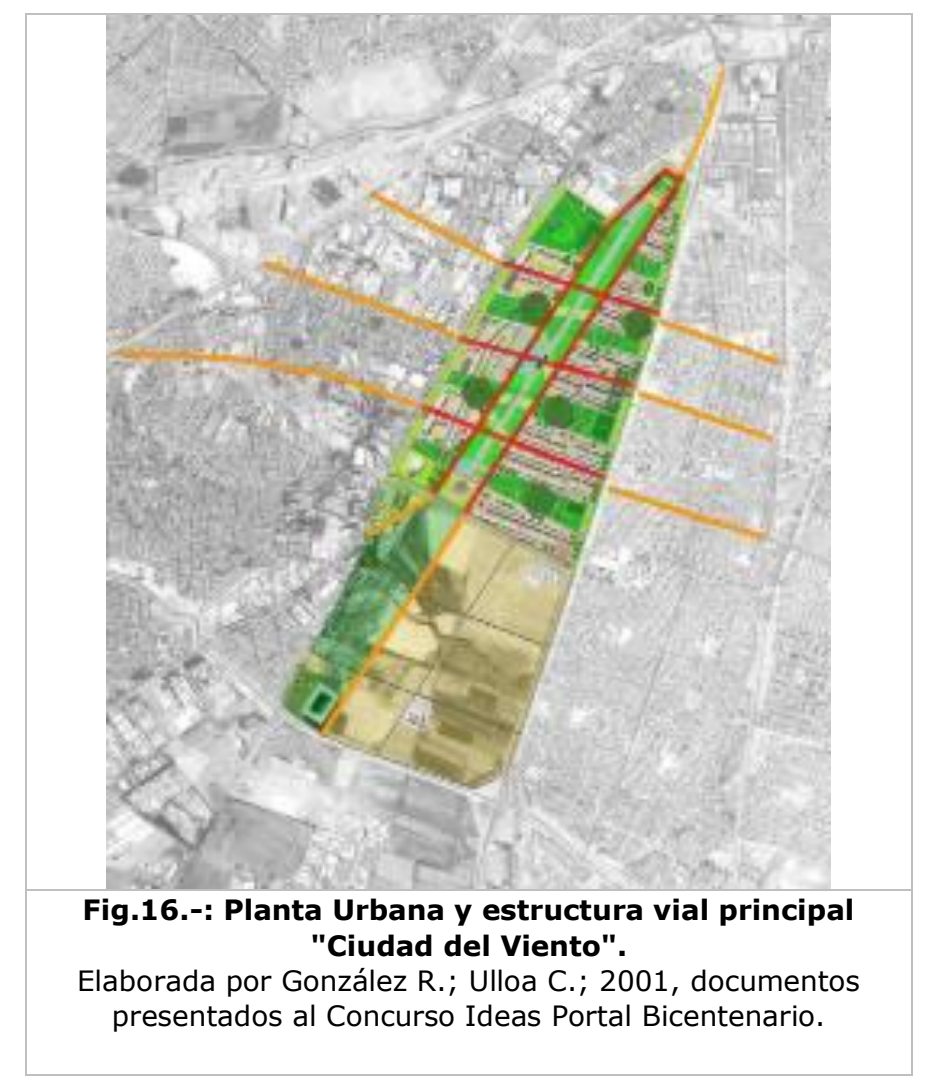

Para el logro de la sustentabilidad social de la propuesta se prevén medidas de mitigación respecto de los posibles procesos de gentrificación en los alrededores de la zona de intervención, "se propone un mecanismo de oferta selectiva de vivienda a los jóvenes de la comuna y entorno, así como a la población económicamente vulnerable que pueda verse afectada por procesos gentrificatorios". Ello se lograría articulando la oferta existente de subsidios mediante "aumentos en los puntajes para acceder a ellos dentro del proyecto, (...) la colocación u oferta directa de empleo en empresas del lugar para residentes de la comuna, (...) bolsas de demanda de vivienda para empleados de empresas del sector". Como parte de los esfuerzos orientados a la sustentabilidad cultural, "se propone un conjunto de equipamiento para la cultura, educación de la población y desarrollo de las artes (...), gran cantidad y variedad de escuelas, así como centros ciudadanos, plazas cívicas, centros juveniles, y recreativos, etc." Esto está cruzado por un cambio en los patrones de educación ambiental urbana, mediante "un modo de educación que promueva actitudes respetuosas con el medio ambiente y que fomente el conocimiento de los procesos ecológicos que ocurren en la ciudad". Apoyando ello, "la forma urbana, da cuenta de la existencia de los espacios de reciclaje, y de biodiversidad en los espacios públicos, de modo de dar acceso a todos los ciudadanos a la evidencia de los procesos ecológicos en la ciudad, y demostrar la 
viabilidad de un modo sostenible de generar el medio ambiente urbano: una ciudad pedagógica en su forma y programa" (González, R.; Ulloa, C., 2001).

Si bien las bases del Concurso de Ideas no mencionan ni hacen referencia al concepto de desarrollo sostenible, o el de sustentabilidad del desarrollo urbano, urbanismo ecológico, o de gestión de la sustentabilidad social económica, ambiental y cultural, la propuesta ganadora sí incorpora estos conceptos basada en la idea de generar un modelo alternativo de ciudad, alternativo a la ciudad que en 2001, y actualmente, se sigue construyendo en Chile.

Es necesario recordar que el discurso del 'Desarrollo Sostenible' al 2001 no era parte integrante de las políticas urbanas chilenas, ni de los discursos sobre la planificación urbana, diseño urbano y programa urbano, dirigidos desde el Estado. Estos eran más bien discursos provenientes del mundo académico y desde las organizaciones multilaterales. En 2001 los planes, programas y proyectos estatales en materia de proyectos urbanos (a diferencia de otras carteras) no hacían alusión al tema de la sustentabilidad a pesar de que este tema era ya un tema discutido en la literatura internacional sobre urbanismo. Este es incorporado a las bases de licitación el Plan Maestro luego del resultado del Concurso de Ideas.

Como resumen, la propuesta incorpora su carácter de modelo urbanización sostenible en tanto releva temas genéricos sobre el diseño urbano sostenible que es posible aplicar a otros entornos urbanos. Ella instaura una forma urbana y nuevos programas urbanos articulados que permiten minimizar el impacto al medio ambiente del conjunto, al tiempo de aumentar su biomasa y biodiversidad, reciclar parte de sus propios desechos, generar parte de la energía que consume, integrarse a la trama urbana circundante. Es portadora de un nuevo modo de vida urbano acorde con los procesos o ciclos ecológicos, y biológicos de la ciudad, mediante un modelo denso en población (eficiente ante el crecimiento urbano), con un alto porcentaje de áreas verdes, equitativo, caminable, con equipamientos y servicios accesibles, con un espacio público activado, y una edificación solar eficiente energéticamente. Un conjunto que respeta la memoria del uso anterior del aeropuerto, por tanto respetuoso patrimonialmente. Se trata de una urbanización que replantea el clásico metabolismo lineal urbano hacia un metabolismo circular, sinérgico, innovador, y productivo.

Dadas estas características es posible hipotetizar que:

1).-"Ciudad del Viento" como "modelo urbano" es el primer Diseño Urbano en Chile de escala de megaproyecto conteniendo criterios de urbanismo ecológico.

2).-"Ciudad del Viento" Plantea tempranamente en Chile temas que hoy están en amplia discusión y debate al interior de la disciplina y en implementación en distintos lugares del globo. Plantea tempranamente objetivos traspasables a políticas públicas urbanas, que hoy son lenta y progresivamente incorporadas producto del avance en la discusión en materia de Diseño Urbano Sustentable. 
3).-La propuesta "Ciudad del Viento", corresponde a un diseño de urbanización sostenible con un sentido modélico, que esperaba ser replicada, y constituye un referente chileno y un aporte al diseño de entornos urbanos sostenibles en megaproyectos de diseño urbano al interior de la ciudad y en proyectos de nuevas ciudades o urbanizaciones.

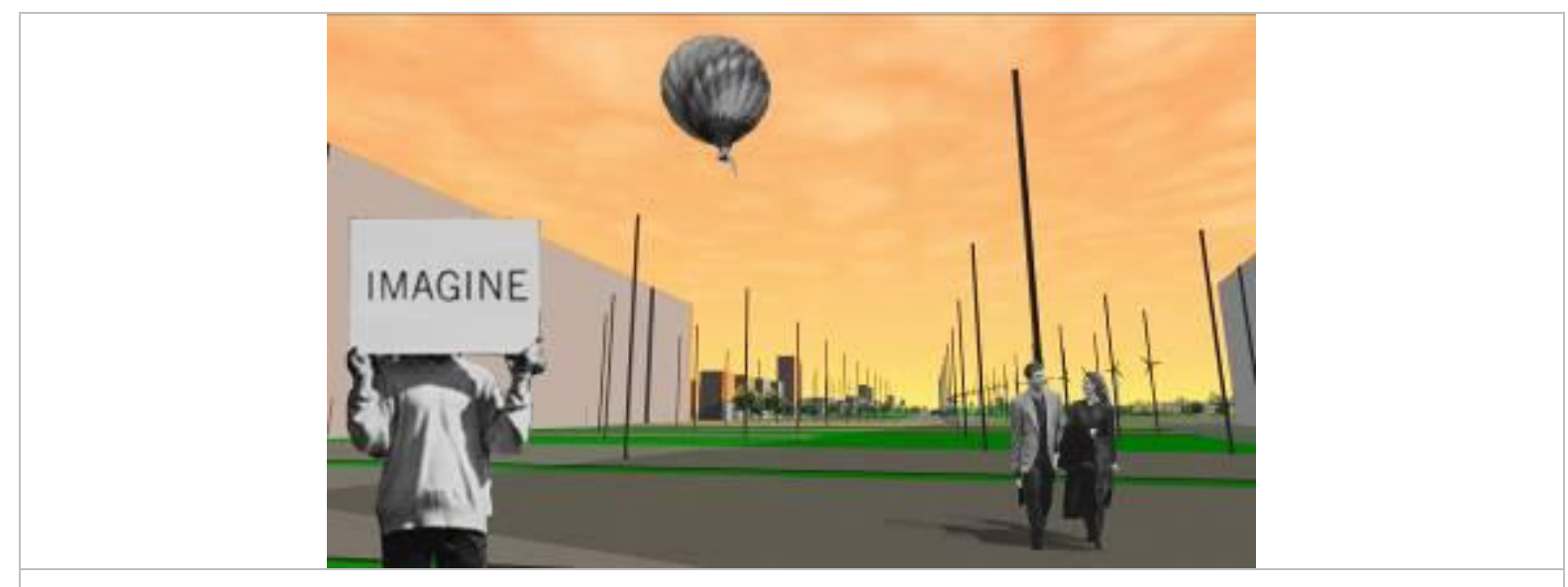

Fig.17.- Plaza de las banderas, al extremo norte del parque en "Ciudad del Viento".

Elaborada por González R.; Ulloa C.; 2001, documentos presentados Concurso Ideas Portal Bicentenario.

\section{2.- Fecundidad de la idea "Ciudad del Viento".}

Patricio Gross, en su libro Sustentabilidad ¿un desafío imposible?, plantea que "los urbanistas están llamados a pensar la ciudad y hacer propuestas contundentes, coherentes, innovadoras, provocativas y accesibles a la gran mayoría de la gente, con el fin de desatar el tan necesario debate sobre los temas urbanos, sus diagnósticos y su futuro" (Gross, Patricio 2002, p.34). Este texto ilustra en alguna medida el rol que un proyecto urbano planteado para el Bicentenario debiese poseer. Es a este respecto que se considera que la oportunidad que posee hoy día el país de reconsiderar la propuesta ganadora del Concurso de Ideas en 2001 y sus criterios de estructuración urbana es una oportunidad interesante. Sobre todo dada la contingencia nacional en la que se requiere articular modelos de gestión sostenible para los entornos urbanos devastados por el terremoto de febrero 2012 y considerando que la estructuración de propuestas urbanas planteadas como sostenibles es un fenómeno recurrente ya desde entrada la primera década del s. XXI, y también que actualmente se encuentran en proceso de diseño y construcción varias propuestas con estas características en el mundo, entre ellas Wanzhuang, el recientemente detenido Dontang, la ciudad que busca cero emisión de carbono: Masdar, Simbiocity, un modelo urbano de gestión, el 
ya clásico proyecto académico de Arcosanti de Soleri, entre otros. Se argumenta ello en función del análisis de la fecundidad actual y posible de la idea de "Ciudad del Viento", como veremos a continuación.

Se plantea que las posibilidades que la propuesta original "Ciudad del Viento" genera, en tanto genera tempranamente un modelo de ciudad sostenible adaptado al contexto nacional, son amplias, dada la aceptación que hoy posee la necesidad de un desarrollo urbano sostenible que cambie el modelo de desarrollo de las ciudades, idea muy difundida en la actualidad y para la cual distintos países del mundo se encuentran elaborando propuestas y para la que hoy existe vastas posibilidades de financiamiento internacional, a las que el proyecto C.P.B. podría acogerse no solo para sus estudios (como los ya elaborados con G.T.Z.). A continuación se presentan algunos de los proyectos que actualmente existen como proyectos de desarrollo sostenible urbano; estos contienen elementos ya enunciados en el proyecto "Ciudad del Viento", en 2001, se agregan estas referencias para invitar al lector a la reflexión respecto la real posibilidad de aprovechar la oportunidad que tiene el país a propósito del momento en que se encuentra C.P.B, para generar un proyecto con las características de los que se muestran a continuación:

A más de 50 años del comienzo de la discusión sobre la "cuestión ambiental" y del aviso sobre las tendencias de urbanización en crecimiento, y a más de 30 años de la emergencia del discurso del Desarrollo Sostenible, se comienzan a visualizar respuestas prácticas por parte de la disciplina urbana y arquitectónica que integran conceptos desde la ecología urbana, desde la economía y producción industrial y de servicios, entre otras. Estas respuestas son cada vez más y más veloces, lo que indica un progresivo cambio conceptual respecto como se piensa la ciudad desde la práctica. En ello el desarrollo de megaproyectos tiene una directa responsabilidad.

Estos proyectos son solo una muestra de proyectos desarrollados con la idea de ciudad sostenible, a distintas escalas y con ideas diferentes, muestran, cómo este concepto de ciudad reconoce la necesidad de establecer diferencias no solo de modelo de gestión, sino de modelo urbano respecto la ciudad tradicional. Son ciudades planteadas como densas, eficientes energéticamente, enlazadas estratégicamente a los sistemas y redes de la ciudad en la que se encuentran, con ambiciones de ser entornos urbanos de cero emisión de carbono, con modelos urbanos que propician la sinergia de las partes de la ciudad, y proponen formas distintas de uso del espacio, e incorporación tecnológica de diversa índole, etc. Estas propuestas, algunas ya en plena ejecución, demuestran que es posible desarrollar modelos urbanos alternativos que además se inscriben adecuadamente en los modelos de mercado existentes, cambiando las tendencias de consumo progresivamente.

Respecto la necesidad de generar modelos urbanos para la construcción de urbanizaciones y ciudades sostenibles, "Ciudad del Viento" plantea consideraciones referidas a literatura que ya es clásica sobre el tema. Resume y condensa en la idea de espacio público productivo los libros sobre ecología urbana escritos desde la década de 
los 90 del s. XX hasta hoy, que recogen las enseñanzas de M. Hougth (1998), V. Betinni (1998), Ken Yeang (1995), Bentley, Alcock, Murrain, Mc Glynn y Smith (1999), J. Tood y N. Jack Tood (1993), M. Ruano (1999), entre otros autores, a su vez basados en estudios sobre economía, ingeniería, ecología urbanismo y sociología, entre otras disciplinas. Aspectos que es necesario revisar para definir acciones replicables en planificación de territorios nuevos, anexados a la ciudad, así como de proyectos de nuevas urbanizaciones y recuperación de las existentes y devastadas por el terremoto en Chile de febrero 2010.

Respecto la fecundidad de la idea planteada en "Ciudad del Viento", es posible observar claramente en la propuesta de Actualización Plan Regulador Metropolitano de Santiago, presentada en diciembre 2008, que los criterios básicos de la definición de la forma urbana adoptada por la propuesta "Ciudad del Viento" han sido considerados para la propuesta que modifica el PRC. Sin entrar a cuestionar o validar la propuesta de Modificación del instrumento normativo, hecho que se profundiza en una reflexión y análisis publicado por Pablo Trivelli (Trivelli $\mathrm{P}, 2008$ ); se considera que esa propuesta toma como referente las ideas respecto la estructuración de conectividades oriente poniente y norte sur y respecto la distribución de áreas verdes planteadas para el caso de Portal Bicentenario Cerrillos. Las imágenes abajo muestran como la modificación del PRMS usa y replica el modelo de estructura urbana desarrollada en "Ciudad del Viento". Los vínculos en la morfología urbana base, estructura vial y de espacios verdes, de ambas propuestas son evidentes. Esto demuestra su potencial aplicabilidad al diseño urbano de otros sectores de la ciudad, y otros entornos urbanos, y sobretodo hace plausible imaginar los potenciales posibles del "modelo urbano" que representa: la potencial organización de corredores verdes portadores de servicios ambientales y el potencial de cambio que generaría el uso o aplicación de los criterios sobre el cambio en el metabolismo urbano asociado a la idea de espacios públicos con carácter productivo-ecológico.

Si bien los porcentajes de áreas verdes planteados y las características ambientales de "Ciudad del Viento" no son mencionados en la modificación del instrumento normativo, se considera que la propuesta usa el modelo de estructura urbana desarrollado a propósito del Concurso de Ideas. Cabe resaltar el potencial de incorporar a estas modificaciones los criterios sobre la urbanización planteados por "Ciudad del Viento", y por tanto el potencial de fecundidad de esta idea. 


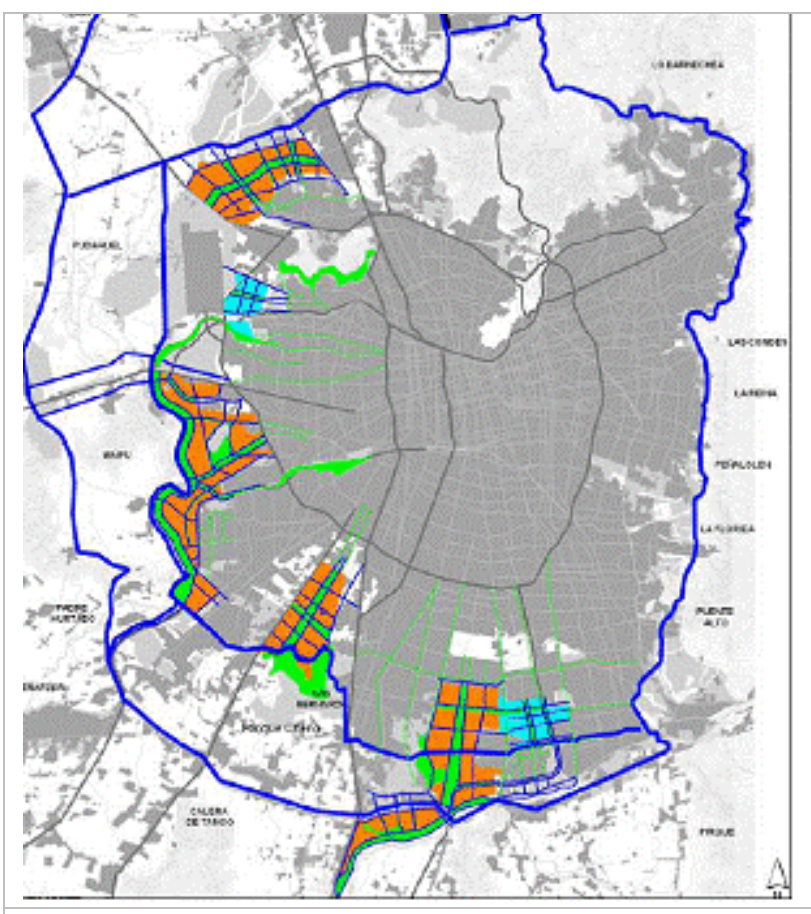

Fig.18.- Propuesta Vialidad troncal y de espacios verdes y síntesis propuesta modificación PRMS. Fuente: Figura 4.1.3. modificación propuesta PRMS octubre 2008 


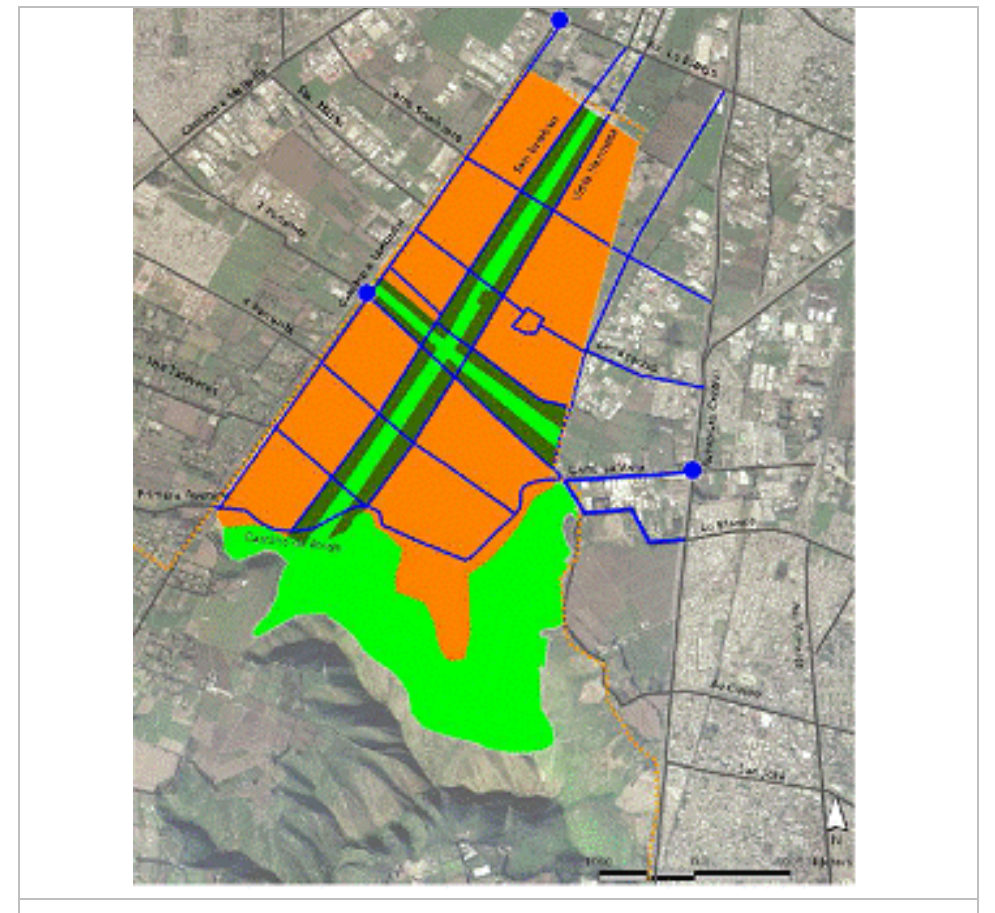

Fig.19.- Detalle propuestas sector C Sur Oriente1 (a continuación de CPB).

Fuente: Figura 4.1.6 modificación propuesta PRMS octubre 2008

Actualmente Chile se encuentra ante la posibilidad de establecer una nueva ciudad en Santa Bárbara a propósito de la catástrofe en la ciudad de Chaitén por la explosión del volcán homónimo. A su vez producto del terremoto ocurrido en febrero de 2010, se hace necesaria la reconstrucción de una buena cantidad de ciudades lo que representa más allá de la catástrofe, una oportunidad de planificación urbana. El proyecto "Ciudad del Viento", planteado en 2001 ofrece una oportunidad conceptual necesaria de ser estudiada y utilizada ante estas oportunidades. A juicio del autor, no ha sido revisada lo suficiente, ni como propuesta para las etapas posteriores del proyecto Ciudad Parque Bicentenario, ni como modelo para potenciales futuras urbanizaciones y por tanto requiere de revisión. "Ciudad del Viento" propuso ya en 2001, ideas que actualmente son vigentes en el discurso sobre la ciudad, y constituyó por tanto una temprana respuesta Chilena al discurso del Desarrollo Sostenible, aplicado al Diseño Urbano. Ideas que son aplicables en el desafío por constituir y reconstruir los 
asentamientos urbanos afectados por dichas catástrofes, desarrollando un modelo alternativo de ciudad.

C.P.B. ha perdido un tiempo valioso para el desarrollo de una propuesta con carácter modélico ya planteada en 2001 con criterios de sustentabilidad hoy vigentes en las principales propuestas urbanas del mundo. Sin embargo, aún hay mucho de los conceptos del proyecto "Ciudad del Viento" que aún pueden ser incorporados a esa y otras propuestas urbanas.

La propuesta "Ciudad del Viento", resultó ser fecunda tanto por las posibilidades que abre al ser considerada por la planificación urbana de la Región Metropolitana en la modificación del PRMS. Fecunda pues sus ideas y estrategias, continúan siendo vigentes, independientemente a su fallida implementación en el terreno del ex Aeropuerto Cerrillos. Y, por tanto, se plantea derechamente la necesidad de estudiar la posibilidad de que el proyecto Cuidad del Viento corresponda a una alternativa aún válida para el terreno, a diez años de su gestación. Considerando que actualmente la evaluación del proyecto encargada por el Presidente de la República, Sebastián Piñera al ingeniero Benjamín Dávila M. abre una nueva oportunidad para recuperar el sentido original de la propuesta, si es que se decide continuar con el proyecto.

\section{3.- Cabe resumir y reflexionar}

- La propuesta original ha demostrado ser fecunda en planteamientos, en tanto planteaba aspectos explícitos sobre sustentabilidad urbana tanto ecológica, como social, de participación, simbólica, y cultural. Aspectos hoy recurrentemente citados en proyectos urbanos de nivel internacional contemporáneos.

- La propuesta "Ciudad del Viento", venía a mitigar las críticas (en ese momento aún no fundadas científicamente, hoy bien fundamentadas) sobre los posibles efectos indeseables, de urbanizar el área, en la ventilación de Santiago. Este aspecto aún no ha sido adecuadamente estudiado e incorporado en cada una de las propuestas planteadas para el paño de C.P.B. Como indica Romero y Vásquez la sustentabilidad de C.P.B. estaría en entredicho en tanto la ubicación del proyecto en medio de un flujo de ventilación de Santiago, le confiere una condición estratégica y altamente sensible ante los cambios de uso de la tierra". Estos autores plantean que "el efecto de rugosidad, debido a la obstaculización que generan las construcciones sobre los flujos de ventilación es un aspecto a considerar en las propuestas" (...). Si bien es cierto, el diseño urbano original del Proyecto Portal Bicentenario considera este efecto al dejar un corredor central paralelo a la dirección predominante de los vientos", el Plan Maestro no lo incluye. Mencionan que "este proyecto inmobiliario debe cumplir con la legislación ambiental vigente y presentar un Estudio de Impacto Ambiental", en tanto el proyecto tal como resultó del proceso de Master Plan, "perturba severa e irreversiblemente los ecosistemas que existen previamente a la construcción de la ciudad". Argumentan que "con una Declaración de Impacto Ambiental, donde se 
asegura que el proyecto no produce impactos, se desconoce el significado ambiental de la urbanización así como los impactos acumulativos y de largo plazo, de este tipo de proyectos, los que requerirían de una Evaluación Ambiental Estratégica, por las significativas transformaciones urbanas y ambientales que generarán sobre toda la ciudad, superando en mucho los efectos que se pueden esperar de un simple proyecto individual "(Romero, H.; Vásquez, A. 2005).

- Hemos visto como las voluntades de búsqueda para generar un nuevo modelo urbano sostenible, fueron reemplazados por criterios generales respecto la sostenibilidad urbana, basados en tímidos enfoques conceptuales para la propuesta y las obras. Si bien, los discursos actuales sobre C.P.B. hacen énfasis en materias de eficiencia energética de la vivienda, y de auto mantención energética del alumbrado público en los parques y de integración social, se considera que estos elementos son adecuados pero aún incompletos si se quiere dar un sello distintivo al proyecto.

- Respecto a la responsabilidad de la herramienta Plan Maestro Flexible en los resultados del proyecto se enuncia que el Plan Maestro Portal Bicentenario, debió estar orientado a factibilizar la idea original, dando coherencia al proceso de definición de la misma, y dejando cero espacio a la pregunta sobre qué variables se desestimaron de la propuesta original y por qué. A modo de hipótesis se plantea que la idea de transformar metabólicamente el espacio urbano aún constituye una idea revolucionaria para los paradigmas de gestión urbana chilenos, claramente ya más difundida a nivel internacional, pero aún difícil de conceptuar no solo por autoridades, sino de inscribir en los modelos de gestión y operación, y marcos normativos y regulatorios actuales.

- Considerando dicha flexibilidad del Plan Maestro, aquella idea que pudo ser matriz bajo la cual se planteara un modelo urbano replicable: "Ciudad del Viento", aún puede constituir una alternativa viable ante el escenario de revisión en el que se encuentra actualmente la iniciativa. Sobre todo considerando que la forma de urbanización de "Ciudad del Viento" permite dar solución a la actual necesidad de pistas de emergencia ante un terremoto como el que azotó a nuestro país en febrero, dado que "Ciudad del Viento" no solo deja despejada la pista y a esta en el centro de un parque perfectamente ampliable, sino que también responde a las principales críticas de los posibles daños medioambientales que la urbanización, al modo del Plan Maestro, generaría.

- Hoy día tanto la gestión como el modelo urbano de CPB son cuestionados y cuestionables. En tanto la consecución de los objetivos públicos planteados para la propuesta requería de una clara voluntad política y de gestión más allá de las tendencias del mercado que inevitablemente reproducen lo que la ciudad tradicional ofrece. En la actualidad más allá de un gran parque y viviendas que potencialmente puedan incorporar criterios de eficiencia energética y mixtura social en los barrios, 
C.P.B. debiese recuperar su estatus de proyecto emblemático, y tiene la oportunidad de hacerlo.

- Queda para la reflexión el texto del arquitecto Felipe Assadi, respecto "aquel Portal Bicentenario al que se le cambió el nombre por Ciudad Parque Bicentenario; y que ya no tiene esos grandes molinos de viento que lo convertían en el más importante proyecto sustentable del país -cuestión que le valió ser escogido para el primer premio en dicho concurso (hace referencia al Concurso de Ideas) y lo peor de todo, de bicentenario le queda bien poco" (Assadi, Felipe, 2009).

\section{Bibliografía}

ASOCIACIÓN PORTAL BICENTENARIO. Plan Maestro Portal Bicentenario. Resumen Ejecutivo. Chile, Santiago.

ASSADI, Felipe "Poco de Bicentenario" Columna en "Vivienda y decoración". El Mercurio. Sábado 23 de Mayo de 2009.

BEACH LOBOS, Myriam; Montealegre Klenner, Alberto "El Parque Portal Bicentenario en Santiago De Chile" Revista de urbanismo n²16, junio 2007 ISSN: 0717-5051.

BETINNI, Virginio 1998, "Elementos de Ecología Urbana" ISBN: 978-84-8164-261-2 Editorial Trotta S.A.

BENTLEY, Alcock, Murrain, Mc Glynn y Smith 1999, "Entornos vitales. Hacia un diseño urbano y arquitectónico más humano, manual práctico", editorial G. Gilli, Barcelona España.

CARMONA, M. (compiladora), Arrese A. 2005. "Globalización y Grandes Proyectos Urbanos. La respuesta de 25 ciudades". Ediciones Infinito Buenos aires ISBN: 9879393-10-4 pags 456 a 458.

DI PACE, M. et.al. "Ecología de la ciudad". Buenos Aires: Ed. Prometeo-UNGS, 2004.

ELIASH, Humberto "Portal Bicentenario; Breve Crónica de un Proyecto Urbano Emblemático" [artículos de revistas]. 2006, Primer Semestre. Publicado en: Revista de Arquitectura UCH, N¹3 (2006: Primer Semestre), PP.56-58.

GONZÁLEZ AGUAYO, Rubén 2006. "Planes Maestros como herramienta de gestión de megaproyectos de diseño urbano liderados por el estado y ejecutados por el sector 
privado: el caso del portal bicentenario cerrillos." En: De Arquitectura 2006 Facultad de Arquitectura y Urbanismo Universidad de Chile.

GONZÁLEZ AGUAYO, Rubén; Ulloa Muñoz Cristian, 2001 Láminas presentación propuesta "Ciudad del Viento". Concurso Internacional de Ideas Portal Bicentenario.

HOUGH M., 1998. "Naturaleza y Ciudad: Planificación Urbana y Procesos Ecológicos". Editorial Gustavo Gili, Barcelona.

LAGOS ESCOBAR, Ricardo 2001 - Discurso 21 de Mayo 2001 Presidente De La República. Archivo Cámara Diputados Gobierno de Chile.

MINVU Gobierno de Chile 2001, "Bases Técnicas Concurso Internacional De Ideas Portal Bicentenario Comuna de Cerrillos - Santiago de Chile".

MINVU Gobierno de Chile 2002, "Bases Técnicas Licitación Plan Maestro Portal Bicentenario Comuna de Cerrillos - Santiago de Chile".

MONTEALEGRE-BEACH arquitectos 2004. página web y archivo proyectos oficina. http://www. mbarq.net/

NAREDO, J. M. "Fundamentos de economía ecológica." IV Congreso Nacional de Economía, Desarrollo y Medio Ambiente, Sevilla. Dic. 1992.

ROMERO, Hugo y Alexis Vásquez. "La comodificación de los territorios urbanizables y la degradación ambiental en Santiago de Chile" Scripta Nova Revista Electrónica de Geografía y Ciencias sociales. Universidad de Barcelona. ISSN: 1138-9788. Vol. IX, núm. 194, 1 de agosto de 2005. Depósito Legal: B. 21.741-98. Texto producido en el marco de Proyecto Fondecyt 1050423. Departamento de Geografía de la Universidad de Chile.

RUANO, M. 1999. "Ecourbanismo. Entornos humanos sostenibles: 60 proyectos." Barcelona, Gustavo Gili. ISBN: 8425217237.

SEREMI MINVU 2008 "Memoria Explicativa Actualización Plan Regulador Metropolitano de Santiago" Santiago, Diciembre de 2008."

SÁNCHEZ, J.M. 2007. "PRINCIPALES OBJETIVOS DEL PROYECTO CIUDAD PARQUE BICENTENARIO". Minuta de trabajo interno, Ministerio de Vivienda y Urbanismo. (La Tercera, 18-06-2007).

TRIVELLI, Pablo, 2008. "Sobre la Propuesta de Modificación de Plan Regulador Metropolitano de Santiago la necesidad de una justificación más sólida ante la ciudadanía" Revista digital el Café de las Ciudades. 
TOOD, J.; Tood N. Jack (1993), from the ecocities to living machines. Nor atlantic books ISBN: $1-55643-150-3$.

YEANG, Ken (1995) Designing With Nature: The Ecological Basis for Architectural Design. McGraw Hill.

\section{ANEXO1.-}

Teniendo como base el trabajo desarrollado por el equipo ganador del Concurso de Ideas y el desarrollado por la Asociación Portal Bicentenario, y el artículo arriba citado "Planes Maestros como herramienta de gestión de megaproyectos de diseño urbano liderados por el Estado y ejecutados por el sector privado: El caso del Portal Bicentenario Cerrillos" (González, R., 2006), a continuación se estructura un resumen comparativo de los principales cambios que sufre la propuesta "Ciudad del Viento" como idea en el proceso de estructuración del Plan Maestro y su transformación en CPB, y se discute cómo ese resultado es producto de una serie de decisiones orientadas por criterios diferentes a los de constituir un desarrollo urbano integrado, y sostenible cultural, social, económica y ecológicamente, considerando los atributos especiales que como bien público el terreno poseía.

En el artículo citado arriba se plantea la hipótesis de que la elaboración de Planes Maestros Urbanos de tipo flexible en el contexto de una gestión pública encargada al sector privado "genera como resultado una visión desvirtuada de las ideas e intenciones originales planteadas para los proyectos, lo que redunda en una progresiva pérdida del contenido de las propuestas. Una visión de desarrollo híbrida entre voluntades con sentido público, cedidas a modelos de desarrollo (urbano) basados en la lógica de los intereses privados basados en las actuales tendencias de mercado" (González R, 2006). Se argumenta algunos de los aspectos por los que la propuesta "Ciudad del Viento" es desprovista de gran parte de su contenido conceptual al desarrollarse el Plan Maestro. Sobre todo de aquellos aspectos que apuntaban a la idea de un desarrollo urbano sostenible, socialmente integrado y marcado carácter público (González, R., 2006).

En estas líneas se discutirá cómo el proceso de elaboración del Plan Maestro modificó dichos objetivos, y se explicará esto en la medida que desde un comienzo de la etapa "Elaboración plan Maestro" la voluntad del MINVU respecto la propuesta ganadora del Concurso de Ideas no fue realizar un estudio orientado a factibilizar la propuesta original sino que la considera únicamente como un referente, en el contexto de un nuevo proyecto. Esto, a modo de hipótesis, sería explicable en tanto el aparato público encargado del proyecto, al 2001 no había incorporado en sus políticas, planes y programas el concepto de sustentabilidad o sostenibilidad urbana, menos el de eco desarrollo urbano. En tanto la propuesta aparecería a los ojos de la autoridad entonces como una propuesta utópica, o de perfil académico. Se sostiene que esta forma de mirar a la propuesta "Ciudad del Viento", constituye una enorme oportunidad perdida para el Estado Chileno para constituir en el ex Aeropuerto Cerrillos un modelo de ciudad realmente sostenible. Opción que se encontraría nuevamente abierta con la paralización del proyecto a partir de mayo del 2010 y su reevaluación. 
REVISTA DE

URBANISMO

ISSN 0717-5051

http://revistas.uchile.cl/index.php/RU/index

Revista de Urbanismo No22 - Junio de 2010 Departamento de Urbanismo - FAU - Universidad de Chile

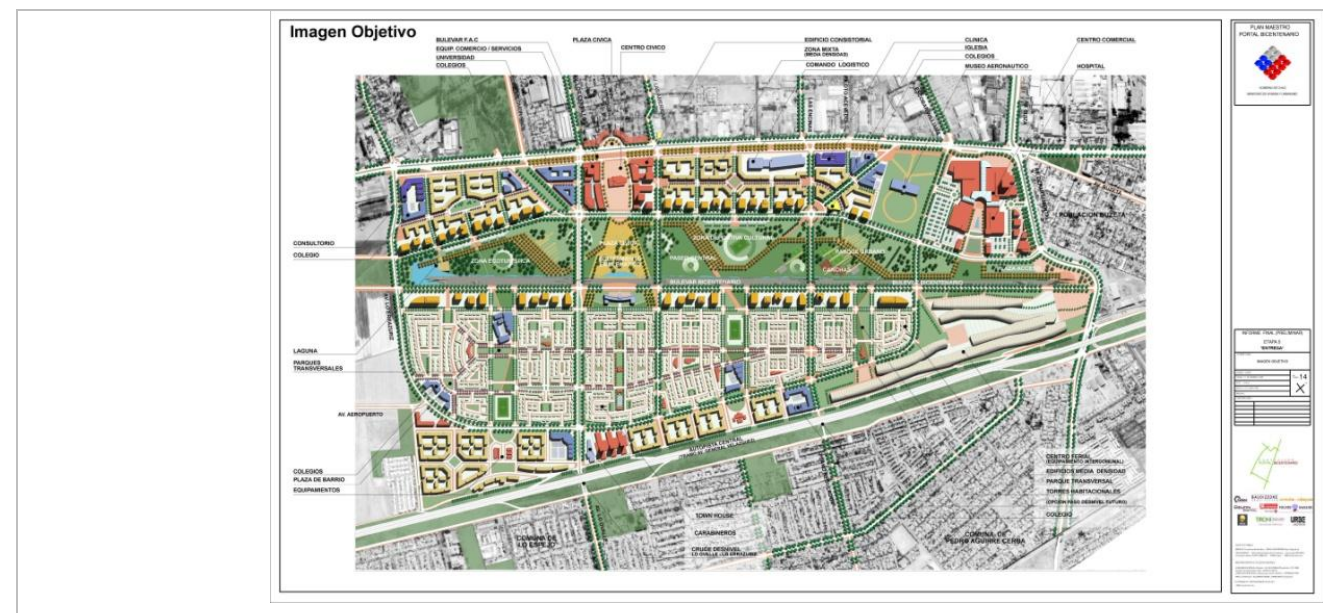

Anexo1.- Fig.1.- Imagen objetivo Plan Maestro urbano Asociación Portal Bicentenario.

Para explicar eso se muestra una tabla que gráfica la comparación de ambos proyectos y se explica cómo se llegó a ese resultado, durante el proceso de elaboración del Plan Maestro. Si bien, no es intención de la presente comunicación poner al mismo nivel un proyecto de ideas, respecto un proyecto en etapa de Plan Maestro y claramente se comprende la necesidad de situar las ideas en un marco institucional y presupuestario y de factibilidades dado, el objetivo no es otro sino destacar la diferencia entre lo que se propuso originalmente y los resultados del plan. El objetivo de realizar esta comparación es contrastar cómo el proceso de formalización de la propuesta desde la Idea a un Plan Maestro, implica un proceso de "pérdida de sentido y de objetivos de la idea original" (González, 2006). Si bien se comprende que ambas Imágenes Objetivo, la de "Ciudad del Viento" así como la del Plan Maestro PB, corresponden a imágenes referenciales, estas son correlato de intenciones de diseño y constituyen en buena medida un paso hacia la conformación de realidades, como lo veremos también para los proyectos agregados posterior y en paralelo al Plan Maestro.
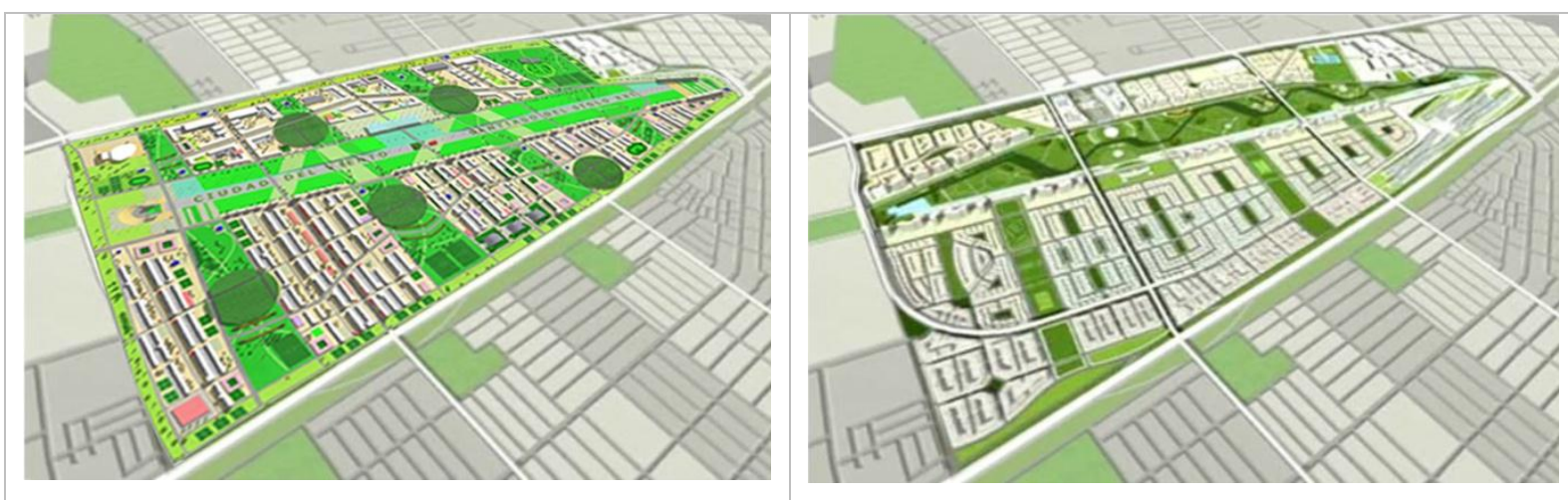

Anexo1.-Figs.2.- y 3.- Comparación de ambas imágenes objetivo.

En las Imágenes 2, 3 y siguientes, en que se comparan ambas propuestas "Ciudad del Viento" y Ciudad Parque Bicentenario, se ha hecho el ejercicio de montar el proyecto "Ciudad del Viento" sobre la base 3D con la que se diseñó la infografía disponible en la web de CPB y se compara las categorías que en ella se presentan casi sin alteraciones (se ha 
REVISTA DE

URBANISMO

ISSN 0717-5051

http://revistas.uchile.cl/index.php/RU/index

Revista de Urbanismo N²2 - Junio de 2010 Departamento de Urbanismo - FAU - Universidad de Chile

juntado algunas categorías para ahorrar espacio en esta comunicación). El objetivo es mostrar claramente como aquellos aspectos descritos antes como elementos de diseño urbano que generan condiciones de sustentabilidad urbana de la propuesta "Ciudad del Viento", fueron reemplazados por criterios de diseño urbano tradicional conducente a insustentabilidad urbana según la bibliografía estudiada y presentada en esta comunicación.

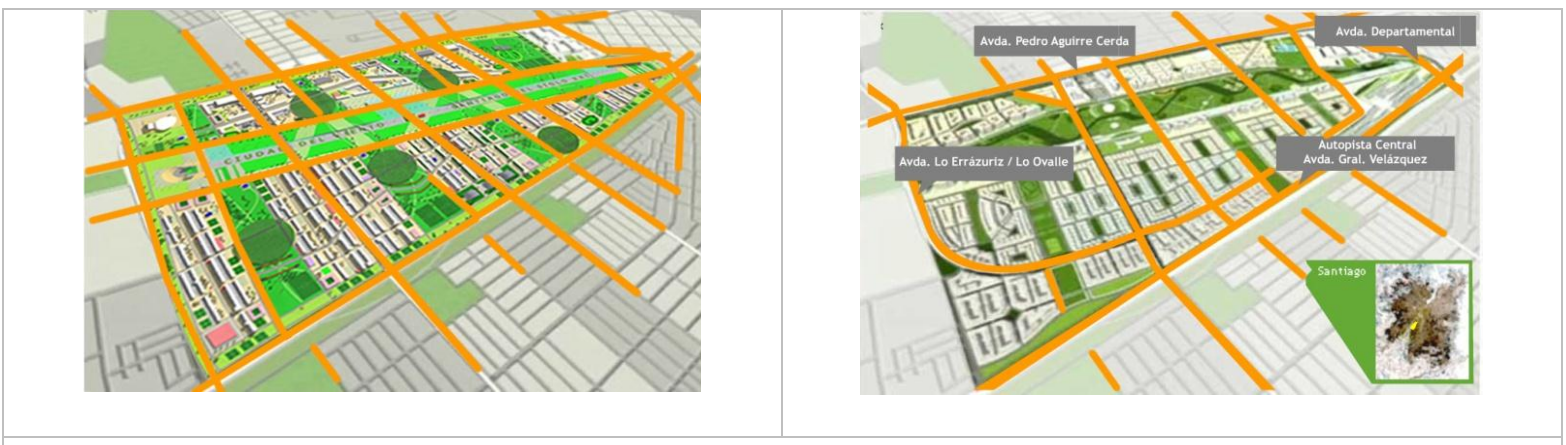

\section{Anexo1.-Figs.4.- y 5.- Muestran la comparación de la estructura vial principal y secundaria y su potencial de conectividad a escala local.}

Es posible visualizar cómo la estructura vial del Plan Maestro (a la derecha) se contrapone a la estructura del proyecto original "Ciudad del Viento" que busca vincularse a las tramas urbanas del entorno del proyecto mediante su calce (independiente de su posibilidad de conexión actual estas se definieron para generar su potencial unión futura); el Plan Maestro se cierra con una calle con forma de herradura, volcando los esfuerzos vinculantes de la trama urbana fundamentalmente hacia la comuna de Cerrillos. Como veremos más adelante esto se refrenda con los planos de zonificación de usos y la propuesta normativa del Plan Maestro. Otro aspecto relevante es el que constituye el lote en el extremo norte de la propuesta, hacia el encuentro entre Autopista Central y Departamental, donde se dispuso un terreno para el proyecto Feria Bicentenario, el que cierra cerca de un kilómetro del proyecto hacia la comuna Pedro Aguirre Cerda. Como veremos en el acápite siguiente.

En materia de transporte el Plan Maestro desestima la potencialidad de las avenidas de borde parque como avenidas portadoras de locomoción colectiva intercomunal dejando el parque en una condición semi-aislada de los principales flujos de transporte restándole accesibilidad directa con la ciudad, y dándole un carácter menos metropolitano que el planteado por el proyecto "Ciudad del Viento"

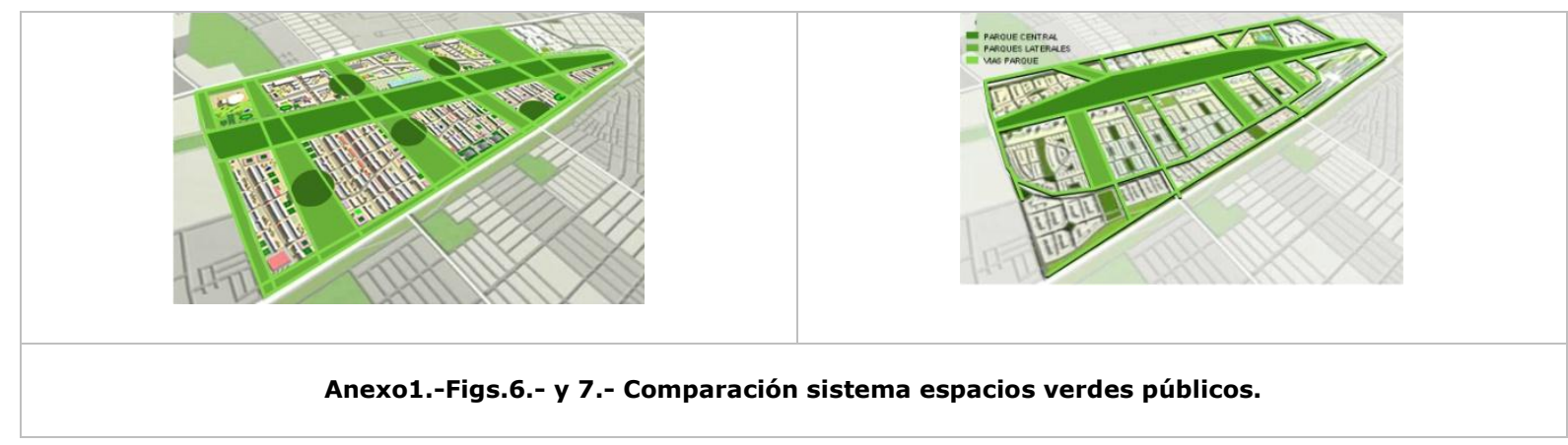

Muestran el traspaso de más de 130 hectáreas de parques, más de la mitad del terreno en espacios verdes públicos, que contenía "Ciudad del Viento", a 50hás de parque central y 20 há de espacios verdes públicos del Plan Maestro. En la propuesta original la pista queda al centro del parque, permitiendo eventuales usos de emergencia, mientras que en el Plan Maestro, su transformación en un boulevard adyacente a una calle impide cualquier uso eventual de la pista. Cabe hacer ver 
que a la reducción de los parques transversales en tamaño, y la inclusión en su interior de equipamiento como colegios, y comercio local (ver imagen 1). Otro aspecto relevante es la variación en la forma del parque, mientras en "Ciudad del Viento" mantenía una forma recta, con una voluntad explícita de proyección al sur y apertura hacia el nudo Departamental, al norte, el Plan Maestro cierra en los extremos la forma del parque y dispone la existencia de barreras en los extremos como lagunas, esculturas y áreas de acceso a centros comerciales que lo cierran en términos de imagen y uso masivo al exterior.
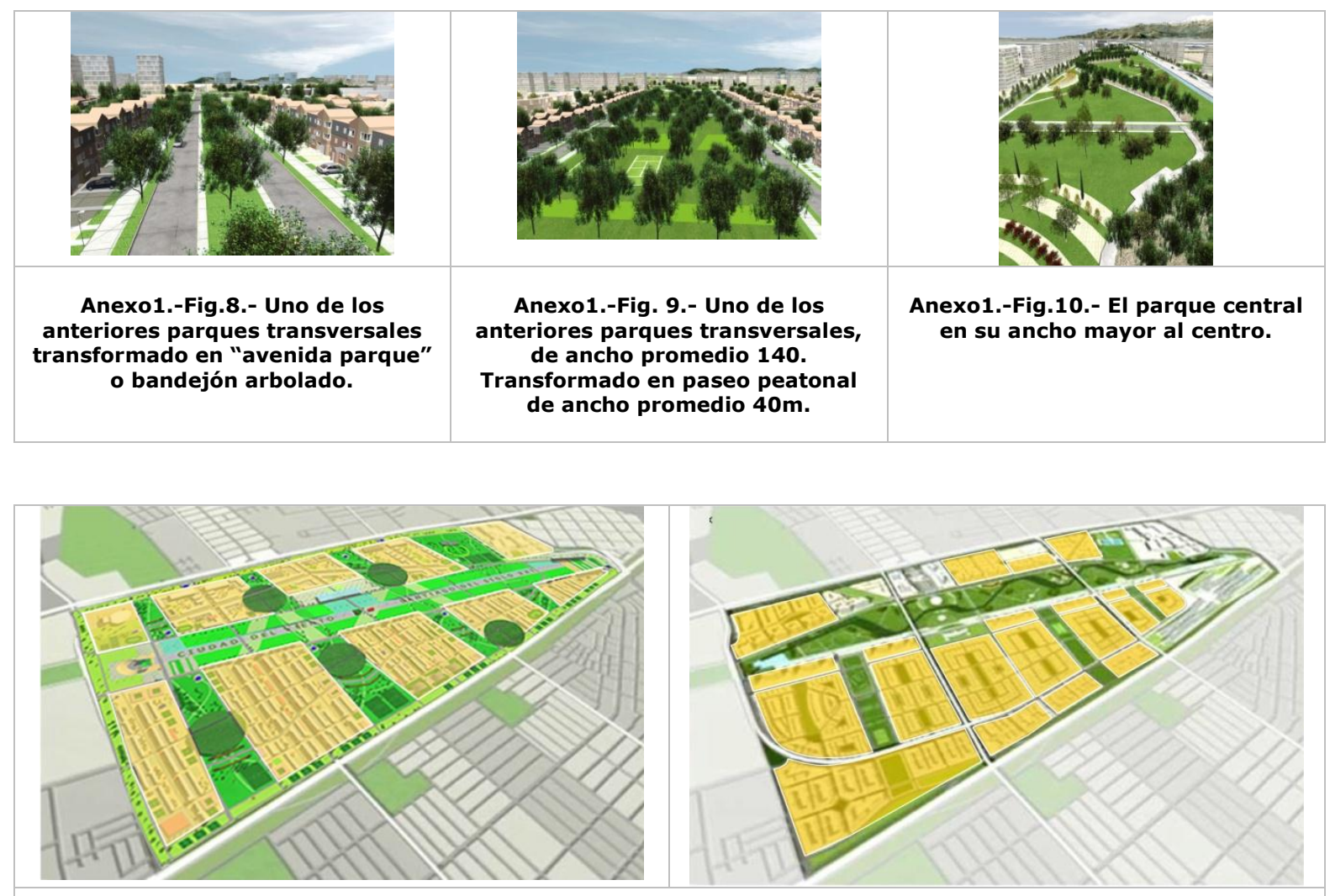

Anexo1.- Figs.11.- y 12. -Se compara la estructuración en el conjunto de las unidades barriales.

La conformación de los barrios para el caso de "Ciudad del Viento", corresponde a unidades concentradas, en altura media a alta, planteadas como unidades densas, con 130 viviendas por há aproximadamente, estructuradas con las vialidades principales conectadas al entorno comunal, y conectadas con parques a sus lados. Estos barrios, mixtos en sus usos de suelo, son concebidos como barrios solares. En el Plan Maestro las estructuras barriales al oriente del parque corresponden a una estructura más bien extendida, en baja densidad, con edificación de baja altura y con unidades barriales más bien cerradas sobre si mismas en torno a plazas interiores. Este modelo barrial no hace más que reproducir la tendencia de urbanización ya existente modificándola levemente en base al estudio de mercados realizado, al incorporar un producto poco ofertado en el contexto nacional, las townhouses. Hacia la Avenida Pedro Aguirre Cerda, P.A.C., al poniente del parque (sector de un tercio del ancho respecto el sector oriente) posee la edificación de usos mixtos siguiendo una diferenciación similar a la planteada por "Ciudad del Viento". Se plantea allí mayor densidad y un carácter compacto, sin incorporar usos productivos ni relacionados al metabolismo urbano, como los planteados en "Ciudad del Viento". 
REVISTA DE URBANISMO

ISSN 0717-5051

http://revistas.uchile.cl/index.php/RU/index

Revista de Urbanismo N²2 - Junio de 2010 Departamento de Urbanismo - FAU - Universidad de Chile

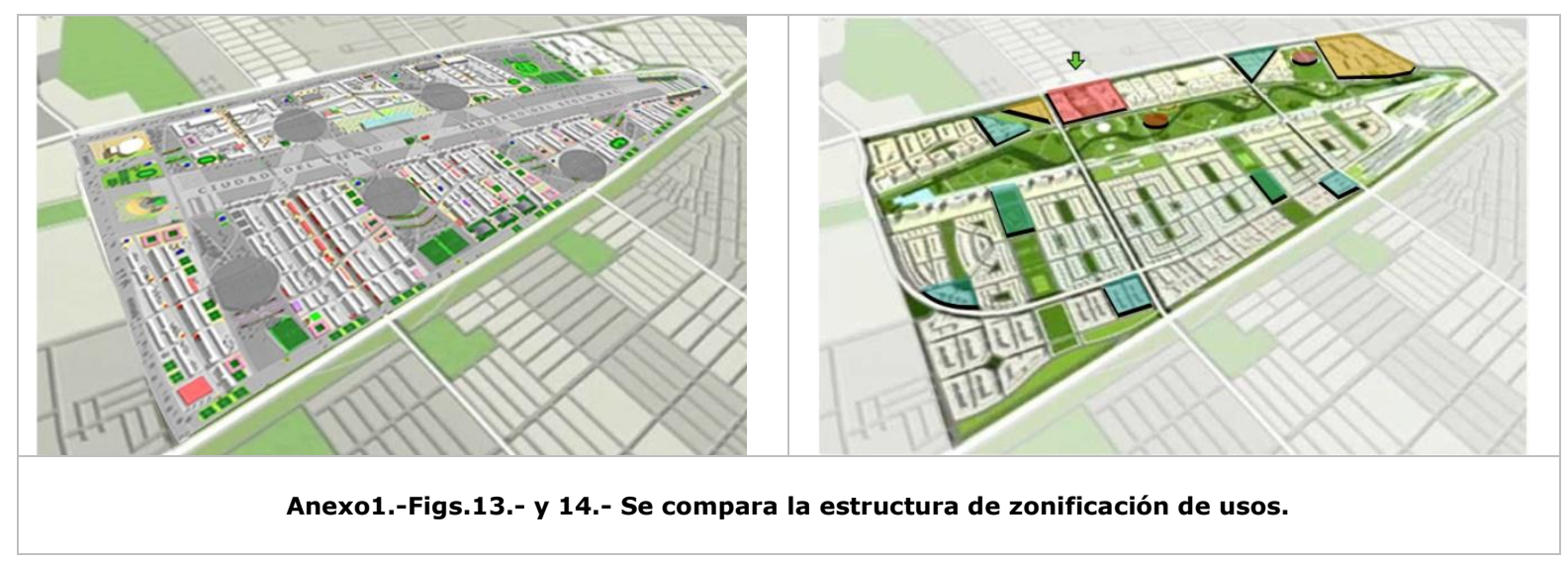

La propuesta original, "Ciudad del Viento", plantea usos mixtos diferenciados en barrios con carácter más residencial al oriente de la pista y barrios con carácter más productivo hacia avenida P.A.C., y plantea una repartición de superficies del mix de usos, homogénea dentro de cada uno de ellos. Por otra parte, la propuesta del Plan Maestro, distribuye al oriente barrios fundamentalmente residenciales, de tipo monofuncional en baja altura, con vivienda en baja densidad y torres hacia el parque y un sector comercial de usos mixtos, en densidad media y alta hacia avenida P.A.C.

En el Plan Maestro el equipamiento y servicios se dispone o bien en los bordes de los barrios como barreras o bordes, o bien en espacios públicos, sobre los parques transversales como una estrategia para restarles superficie, sus ubicaciones son definidas por las posibilidades que brinda la estructura vial y el potencial de centralidad que esta define. En "Ciudad del Viento" los servicios y equipamientos se atomizan, y distribuyen homogéneamente en los barrios privilegiando ubicaciones de mayor centralidad para el comercio y servicios y los bordes hacia los parques para el equipamiento. Se ubican en función de su accesibilidad peatonal y para dar seguridad y vitalidad al espacio público. Programas especiales como el Centro Cívico y la Casa Presidencial se disponen hacia el interior del proyecto, con el objetivo de vincular el proyecto a la comuna de Cerrillos, a la intercomuna, e incluso a nivel nacional, a través del turismo urbano y uso cotidiano. En el Plan Maestro el Centro Cívico se dispone hacia PAC, vinculándose a la centralidad ya existente de dicha avenida, centralidad que es reforzada con el comercio y servicios dispuestos por el proyecto hacia ella (mall, colegios, consultorios entre otros).

La atomización del programa de equipamiento y comercio de "Ciudad del Viento" se contrapone directamente a la lógica de concentración del comercio planteada por el Plan Maestro que dispone un Centro Comercial, en el extremo norponiente del paño urbano, sobre unos terrenos que fueron agregados a posterior al Plan Maestro y que al momento del Concurso de Ideas estaban fuera del terreno de trabajo. Esta voluntad de concentrar el comercio en un centro comercial niega la posibilidad de generar economías locales al interior de los sectores residenciales y por tanto desactivando el uso intensivo del espacio público. En "Ciudad del Viento" el comercio se distribuye en las calles, agregado a las edificaciones residenciales complementando el uso de las mismas y dotando de condiciones de centralidad y complementariedad de usos a los barrios. Como resultado se obtiene una desconcentración de la oferta urbana, y una mayor potencial sinergia entre actividades diferentes, se busca como se dijo anteriormente una ciudad pedagógica. 


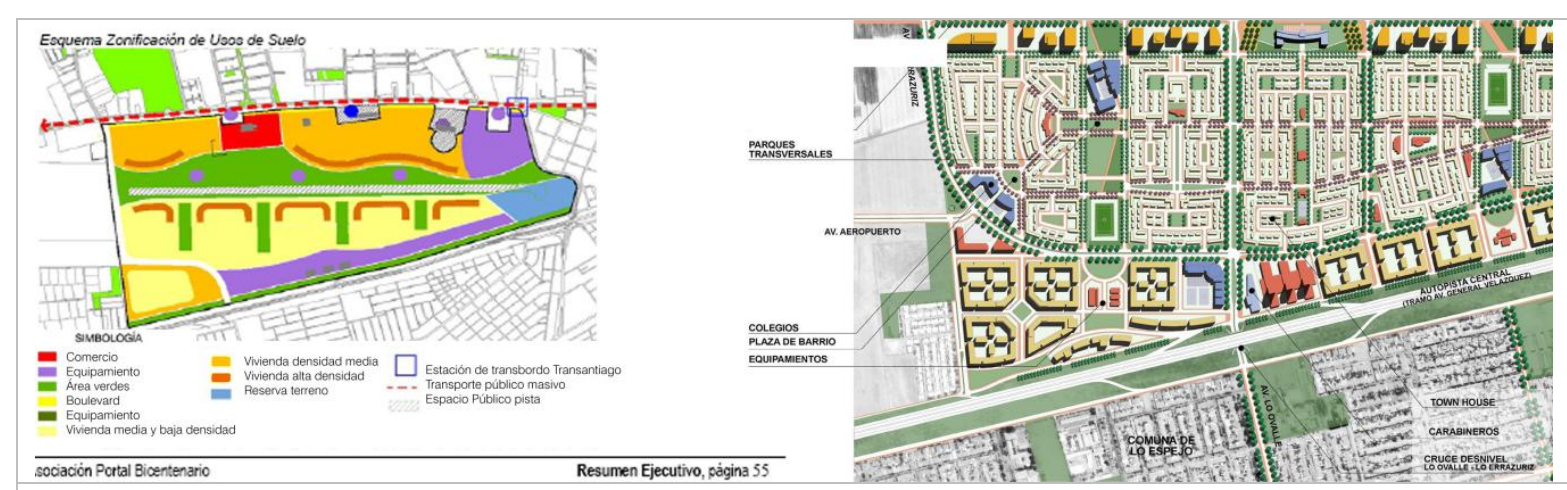

Anexo1.-Figs.15.- y 16.- Zonificación de usos de suelo y programas de equipamiento localizados en Imagen Objetivo Plan Maestro.

Como se puede observar en las imágenes arriba a la izquierda, la propuesta conceptual de definición usos de suelo planteado para el Plan Maestro, claramente posee una estructura urbana menos inclusiva respecto las comunas de Pedro Aguirre Cerda y Lo Espejo, que "Ciudad del Viento". El desarrollo de la Imagen Objetivo (a la derecha) refuerza la barrera hacia la carretera planteada por la zonificación, obstruyendo espacios verdes públicos mediante la disposición de lotes dispuestos para equipamiento, y posicionando otros equipamientos como carabineros justo en el único traspaso hacia la comuna vecina de P.A.C.

Como explicación de este fenómeno de cambio podemos plantear que la formulación de la propuesta de Plan Maestro supone una ruptura profunda de paradigmas entre el concepto de sustentabilidad manejado por el aparato público de la época y el agente privado encargado de desarrollar el Plan Maestro, y el manejado por los creadores del proyecto ganador del Concurso de Ideas. Distancia que se ha acortado con los años, dado el avance en materia de discurso desarrollo sostenible aplicado al Urbanismo. Era justamente rol del Plan Maestro, generar una claridad y potencia conceptual para la propuesta, plausible y que contemplara todos los aspectos, minimizando las críticas que pudiesen afectar al proyecto, incorporando las variables adecuadas y necesarias. Sin embargo, la propuesta del Plan Maestro Portal Bicentenario, no sólo se aleja de la propuesta conceptual de "Ciudad del Viento", sino que acerca la iniciativa a lo que ya el mercado estaba desarrollando a nivel de tendencia. Como podemos ver en la actualidad son pocos los aspectos que diferenciarían el modelo urbano de C.P.B. de la oferta inmobiliaria general para la región Metropolitana.

Como se puede ver en ANEXO 2.-, los proyectos que se desarrollan en paralelo y posteriormente al Plan Maestro si bien no son en general coincidentes con las formulaciones del proyecto original, progresivamente se van a cercando a los objetivos de sustentabilidad planteados por la visión de desarrollo del proyecto "Ciudad del Viento", ello debido al propio calce epocal de estos temas con temas de interés y contingencia nacional e internacional y con la progresiva definición y ampliación del presupuesto asociado a la agenda de sustentabilidad.

\section{ANEXO 2.-}

Paralelamente a la construcción del Plan Maestro, y una vez que ya se había establecido una Imagen Objetivo preliminar, y una estructura de distribución del terreno, se desarrollaron distintos concursos de ideas los que son agregados al resultado del Plan Maestro, e incorporados a la definición de su Imagen Objetivo final. Estos se mostrarán en orden temporal.

En 2004 el MINVU convoca a la realización del Proyecto para el Recinto Ferial y Centro de Convenciones Internacional de Santiago (RFCCIS), mediante un concurso de ideas, en el Marco de la XIV Bienal de Arquitectura. Este proyecto se enmarca en las obras de revitalización urbana impulsados por el Estado para posicionar a Santiago como una "Ciudad Región de Clase Mundial, plataforma para negocios en América Latina", y para ello se conformó un Consejo Público- 
Privado $^{1}$. Si bien este proyecto no se encuentra vinculado de forma irrevocable al Plan Maestro, se agrega a su imagen objetivo, y es posible visualizar en él ciertas tendencias discordantes con el sentido del proyecto "Ciudad del Viento". Aspectos fundamentalmente basados en el potencial de conectividad e inclusividad que el proyecto tiene para con las comunas de Pedro Aguirre Cerda y Lo Espejo.

El concurso del proyecto para el RFCCIS es ganado por los arquitectos Martín Alonso, Daniel Rosenberg, Daniel Wurman, organizados bajo el nombre de WAR. Ponen como premisa para la propuesta una condición de no lugaridad, "en vista de que las bases plantean la posibilidad de elegir una de tres ubicaciones alternativas para el proyecto de Feria en 'Santiago" (WAR, 2004). Proponen "un sistema más que un edificio propiamente tal, útil de cambiar la localización o el programa, adaptable a cualquier localización que se elija inclusive transportable mediante un sistema de mecano que incluso permitiría su traslado" (WAR, 2004). La forma del proyecto resulta de la aplicación de un sistema constructivo constituido por un marco triarticulado estandarizado e idéntico, repetido trescientas cuarenta y cuatro veces y deformado dinámicamente a partir de las articulaciones de la pieza. Se diseña un edificio de $100.000 \mathrm{~m}^{2}$, que según sus autores es "complejo en su forma y rico en sus espacios, en un sistema susceptible de ser localizado en cualquier parte: abierto, capaz de generar infinitas formas, de acuerdo al sitio, al encargo, que permite la prefabricación, abarata los costos y disminuye los imprevistos de la construcción dado su montaje paramétrico" (WAR 2004).

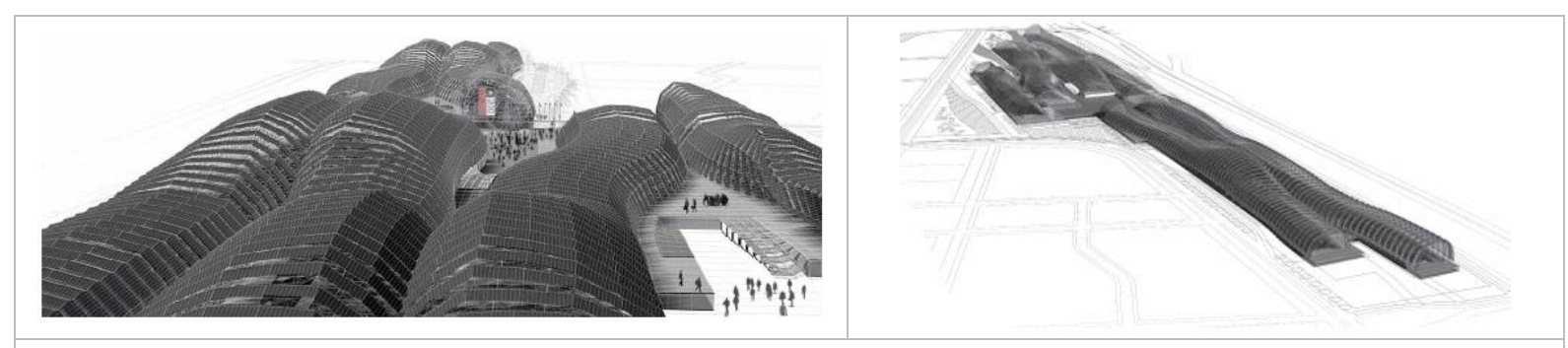

Anexo2.- Figs.1.- y 2.- Proyecto ganador Concurso Ideas para Recinto Ferial y Centro de Convenciones Internacional de Santiago. WAR 2004.

Esta adaptabilidad o flexibilidad no cuestionable en sí, no tendría ninguna observación si, en la propuesta de WAR y, por sobre todo, en la estructuración de las bases del concurso y en la selección del jurado del concurso no hubiese implícita una minimización de las variables de estructuración urbana para dar jerarquía a una estrategia centrada únicamente en el edificio $y$, por tanto, que hace irrelevante el potencial de articulación urbana sinérgica con su entorno inmediato, así como los potenciales de conectividad que la ciudad requiere a escala de barrio. En palabras del equipo ganador: "un edificio de $100.000 \mathrm{~m}^{2}$ no puede pasar desapercibido, su impacto simbólico puede ser enorme, hasta el punto de transformarse en un icono. El programa debe resolverse en un gran edificio que, por su forma y disposición permita la subdivisión interior necesaria según el evento a organizar, pero que se vea y sienta como un edificio gigante (WAR 2004). Por otra parte las bases del concurso para el Recinto Ferial y Centro de Convenciones planteaban que: "se necesitan grandes luces libres de estructura y grandes alturas, más que espacios específicos" argumento que recoge WAR para buscar una estructura que genere "un edificio que se pueda ocupar totalmente con una sola exposición, o con 20 o 30 más pequeñas(...), que logre una gran luz, gran altura y un espacio diáfano (...) capaz de funcionar en una diversidad de escalas (...), un edifico de carácter más bien topográfico, que contraste con la típica edificación recta y refuerce su impacto urbano, a la vez que su forma poco tradicional generaría un impacto mediático e icónico" (WAR 2004).

A juicio del autor de esta comunicación, producto de esta búsqueda acontextual de la arquitectura planteada, centrada en la técnica constructiva más que en el resultado espacial y funcional del edificio en interacción con su entorno inmediato, el proyecto resultante genera un refuerzo de la barrera urbana que constituye la Autopista Central (ex Avenida General Velásquez) ubicada en el perímetro oriente del terreno del proyecto. Además de responder negativamente ante aspectos de seguridad y apropiación del espacio público inmediato a la propuesta. Esto va en directa negación de las ideas planteadas

1 Integrado por la Intendencia de Santiago, la Cámara de Comercio, la Cámara Chilena de la Construcción, la Secretaria Regional Ministerial de Planificación, la Dirección Regional de CORFO, la SOFOFA, el Santiago Convention Bureau, la Coordinadora General de Concesiones del MOP y la Secretaria Ejecutiva de la Dirección Regional de las Obras del Bicentenario. 


\section{REVISTA DE}

\section{URBANISMO}

ISSN 0717-5051

http://revistas.uchile.cl/index.php/RU/index

por la propuesta "Ciudad del Viento", en tanto esta busca la mayor integración posible actual o futura con las comunas de PAC y Lo Espejo, mediante el calce de las tramas urbanas de ambos bordes separados por la Autopista Central y mediante la articulación programática en las tres vías de traspaso que vinculan a las comunas mencionadas con el parque central y los barrios portadores de la oferta urbana de Portal Bicentenario.

La morfología de la ciudad sustentable planteada por "Ciudad del Viento", como una ciudad diversa, multifuncional, heterogénea, compleja y rica en usos, es un modelo contrapuesto a la monofuncionalidad de un espacio de uso temporal, y trabajado en su concepción del límite arquitectónico como un icono para ser visto desde la carretera, negando toda relación funcional con el espacio público, y negando toda potencialidad de sinergia con su entorno inmediato, más allá de las sinergias estratégicas que un proyecto icono traería a la comuna y ciudad, aspecto parcial si se considera que dicho proyecto se encuentra circunscrito a entorno en el que hay mataderos, poblaciones con altos niveles de pobreza, segregadas espacialmente y altos índices de delincuencia.

A juicio del autor y dada la argumentación planteada si bien la búsqueda parece pertinente a las bases planteadas y al lote predefinido por dichas bases, se estima que no es adecuado generar una forma urbana como resultado de una única variable, en este caso, del sistema constructivo aplicado, en tanto este tipo de operaciones desestiman variables urbanas básicas que generan impactos indeseables a distintas escalas urbanas, y sobre todo en la experiencia de vivir el espacio urbano. Se considera además que dado el largo de esta propuesta, su impermeabilidad limita en el futuro los potenciales conectivos a escala barrial de la ciudad. Para este caso una propuesta más adecuada hubiese cuestionado la decisión de mantener indiviso un terreno urbano de $0,7 \mathrm{~km}$ de largo en tanto la propia flexibilidad argumentada como necesaria implica hacerse cargo de los futuros posibles de dicho terreno una vez que el proyecto ya no se encuentre en ese lugar ${ }^{2}$.

En 2004 fue adjudicado por la oficina Montealegre - Beach Arquitectos el "Proyecto Parque Central Ciudad Parque Bicentenario", para el diseño definitivo del parque más grande a ser habilitado en Santiago a la fecha. Este proyecto según Beach y Montealegre K, rescata en su diseño la pista de aterrizaje, transformándola en un paseo peatonal, dispone un paseo central de hasta seis hileras de plátanos orientales, un circuito de ciclovía y pista para un bus recorre ambos elementos, circuito que distribuye estaciones con equipamiento como baños, kioscos y camarines. En el extremo sur del parque, una laguna de $18.000 \mathrm{~m}^{3}$ sirve como estanque de de riego, reserva aviar y paseo de botes, mientras en el extremo norte un espejo con juegos de agua y un monumento de $30 \mathrm{~m}$ de altura conforman la Plaza Bicentenario. A ambos lados del paseo central se configuran áreas de: arborización tipo bosque, cuadros ecológicos, una gran pradera de Césped de 9,9hás. zonas de picnic, áreas deportivas, un jardín de otoño y de primavera. Como equipamiento futuro se ha propuesto un biodomo, un museo, un cine tridimensional y un picadero. Además de las especialidades, el proyecto incluyó el diseño de mobiliario y señalética, la plantación de 61 especies arbóreas en un total de 3397 árboles" (Montealegre-Beach 2004, Beach Lobos M.; Montealegre Klenner A. 2007).

2 Es necesario recordar cómo la carretera norte sur que atravesó la trama urbana de Santiago dividió al centro de la ciudad de Santiago en dos áreas (Stgo. centro y Stgo. poniente) de desarrollo diferenciado, las que se han integrado recientemente por una serie de puentes que hoy conectan e integran a la comuna gracias a la posibilidad que brinda la trama urbana original y la estructura vial de ambos bordes, en tanto coinciden. 


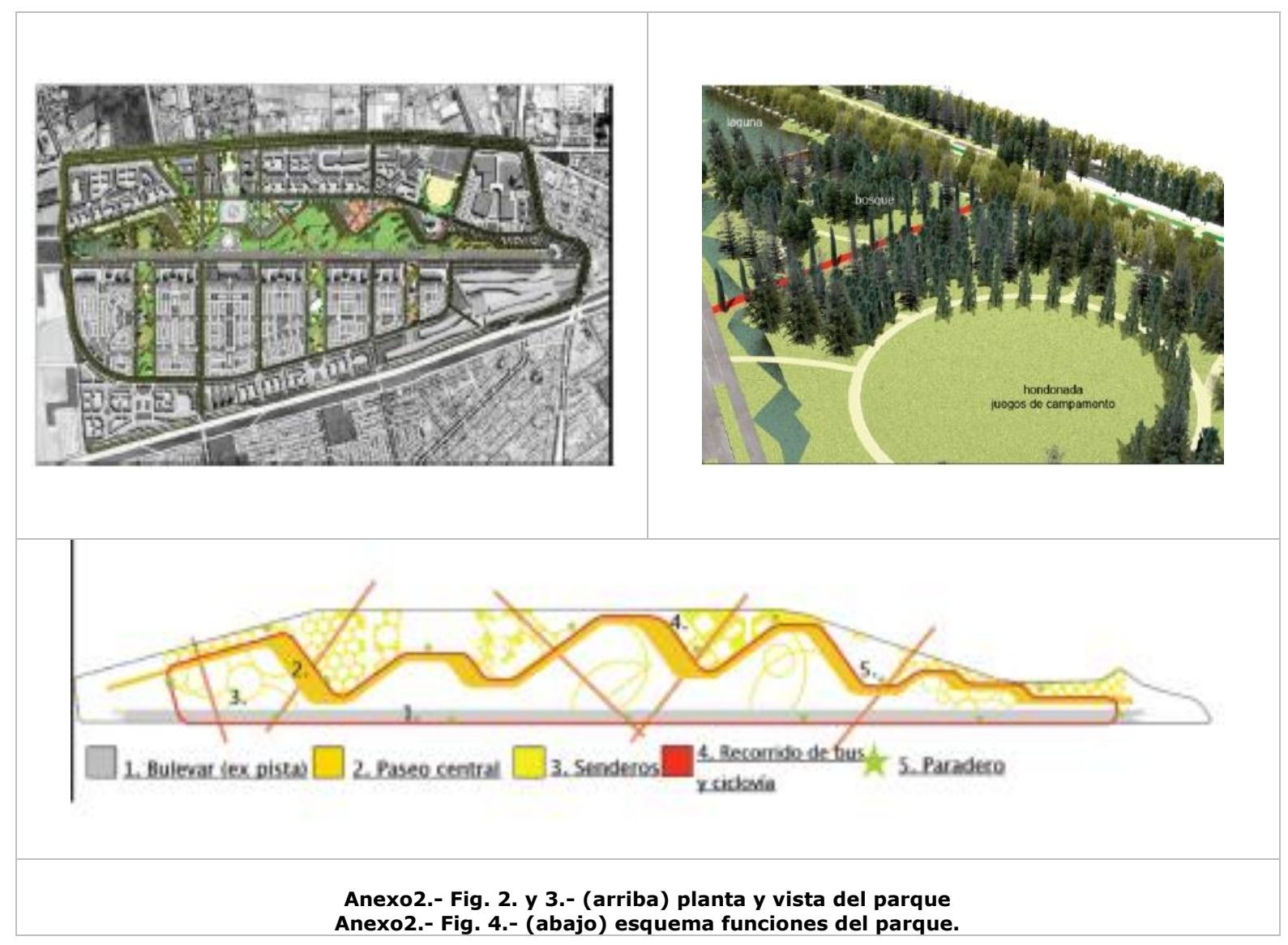

La propuesta ganadora de la licitación para el parque portal bicentenario incorpora solo algunos de los aspectos relacionados con el rol del espacio público planteados por el proyecto "Ciudad del Viento".

Este proyecto si bien posee una lógica más coincidente e integradora de las ideas planteadas en el proyecto "Ciudad del Viento", lo que se evidencia al mantener ciertos elementos como las tres plazas simbólicas en los extremos y al centro de la pista (aunque temáticamente no tienen el mismo rol), o la incorporación de espacios naturalizados, la incorporación de áreas de parque con características pedagógicas, la vinculación del parque con senderos hacia los barrios, la existencia de arborización variada y densa. Sin embargo este diseño e idea, no refleja íntegramente el espíritu de la propuesta original, principalmente pues se pierde la idea de parque ecológico como unidad funcional metabólica para el sistema urbano, asignándole un rol tradicional al espacio público de la propuesta. Si bien es cierto este aspecto no estaba incorporado en las bases de licitación, y tampoco en la asignación de tiempos de desarrollo del proyecto, se estima que el resultado es un parque tradicional con aspectos ambientalmente amigables, dejándose de lado aquellos aspectos vinculados a la configuración de espacios públicos de tipo productivo-ecológico. En definitiva se pierde la idea de que el parque funcione como una máquina metabólica para la ciudad.

Otro proyecto incorporado al Plan Maestro es el resultado del Concurso para el Centro Cívico de Cerrillos que resultó ser más respetuosa con los principios originales planteados por "Ciudad del Viento". En febrero de 2008, el Centro Cívico Portal Bicentenario desarrollado por la oficina Eliash Arquitectos, "propone un sistema de espacios públicos interconectados: la Plaza Consistorial ubicada frente a la nueva Municipalidad de Cerrillos, la Plaza del Aire ubicada entre el ex terminal y el parque central de carácter recreacional. Además se considera la Plaza Diagonal ubicada entre Av. Pedro Aguirre Cerda y el 
REVISTA DE

URBANISMO

ISSN 0717-5051

http://revistas.uchile.cl/index.php/RU/index

Revista de Urbanismo $\mathrm{N}^{\circ} 22$ - Junio de 2010

Departamento de Urbanismo - FAU - Universidad de Chile

Parque Central de carácter lúdico y recreacional, predominantemente verde. Enfrentando al parque central se localizan cuatro torres de uso privado, en tanto que hacia Avenida Pedro Aguirre Cerda se localizan los edificios de uso público: la Municipalidad, la Comisaría de Carabineros, el Consultorio de salud y comercio a escala local" (Eliash, 2008).

Como sistema de obtención de energía para iluminar el espacio público el equipo de Eliash propone aerogeneradores tal como la plaza de los molinos original de la propuesta "Ciudad del Viento". A la fecha de presentación de "Ciudad del Viento" la tecnología de molinos omnidireccionales no había sido masificada aún y se desestimó por considerarse poco rentable y potencialmente improductiva, sin haberse ejecutado los estudios de factibilidad respectivos. Con la Plaza del Aire se recuerda y hace referencia simbólica mediante la nominación de este espacio público al sentido de la propuesta original, el viento. Se puede hipotetizar que el conocimiento por parte de H. Eliash, del proyecto "Ciudad del Viento" y la propia vivencia de haber participado en varias etapas posteriores, como contraparte de los ejecutores del Plan Maestro, pueden haber influido positivamente y a juicio de este autor acertadamente, en su voluntad de respetar la idea original de vincular el Centro Cívico a la memoria del aeropuerto y a la referencia a través de los molinos del cambio hacia la administración urbana sostenible, reconociendo la idea original del proyecto y devolviendo parte de su sentido a la propuesta.

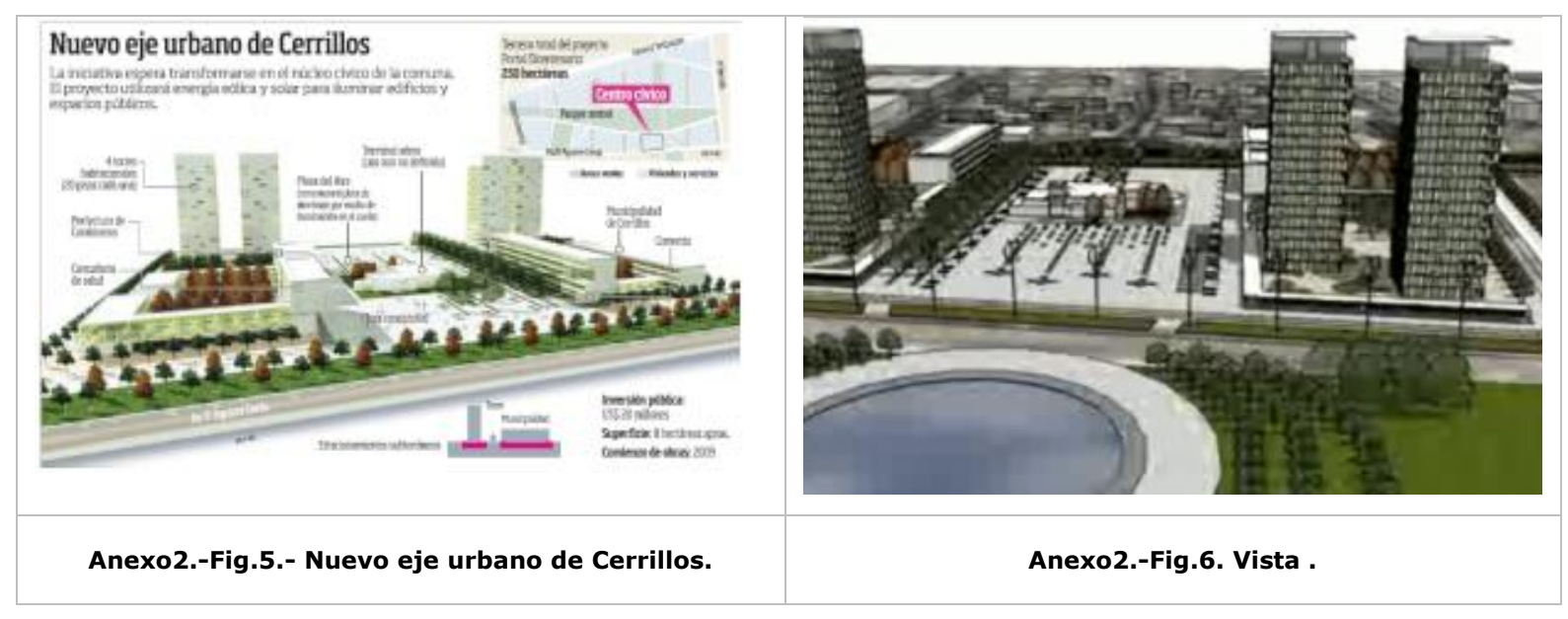

Como hemos visto, con el desarrollo del Plan Maestro la propuesta original fue modificada hasta perder su sentido original. Sin embargo, tanto en el concurso del parque como el del Centro Cívico, ya establecen algunos puntos de vínculo con el proyecto original. Varios años después de haber sido desestimadas las ideas sobre la incorporación de criterios de sustentabilidad ambiental de la propuesta, esta se comienza a retomar. Esta voluntad de regreso al sentido del proyecto original se establece además en una definición de objetivos interna en el equipo de CPB, en 2007, cuando se plantea que "el proyecto Ciudad Parque Bicentenario presenta tres grandes objetivos que debe trabajar durante su desarrollo: Calidad Urbana, Sustentabilidad Ambiental e Integración Social" (Sánchez, 2007).

En esa línea de trabajo se desarrollaron varios estudios posteriores en concordancia con una alianza que CPB realizó con La Comisión Nacional de Energía (CNE), Programa País de Eficiencia Energética (PPEE) y Deutsche Gesellschaft für Technische Zusammenarbeit (GTZ) en el marco de un convenio de cooperación con el Servicio de Vivienda y Urbanismo (SERVIU) de la R.M. Estos estudios analizan la factibilidad de establecer elementos de eficiencia energética para las propuestas y futuras licitaciones de vivienda, los que se incorporan posteriormente como antecedentes para la licitación de paños urbanos que desarrolla la coordinación del proyecto (www.ciudadparquebicentenario.cl). De este modo se estudia abastecer de energía eléctrica al futuro parque residencial mediante una planta de biogás alimentada por desechos. También estudia usar paneles solares para la iluminación de espacios públicos, y calefaccionar edificios públicos con los desechos orgánicos. Algunos de los estudios para desarrollar el proyecto fueron entre otros: "Análisis y simulación de la demanda energética en Edificios Modelo Ciudad Parque Bicentenario" desarrollado por Bustamante y Encinas, Asesorías en sustentabilidad; "Análisis de la factibilidad de implementación de colectores solares térmicos en Edificios Modelo Ciudad Parque Bicentenario" desarrollado por Poch Ambiental y Trans Énergie (www.ciudadparquebicentenario.cl).

Otro estudio analiza el uso de energías no convencionales provenientes de biomasa y la solar térmica. En el primer caso se utilizarán desechos orgánicos domiciliarios (a través de la separación de basura) y residuos como pasto cortado, ramas y hojas del parque siendo posible mediante el biogás, generar con el proyecto un megawatt de energía. Para generar calor se estudian colectores solares, que se instalarían en la superficie de los techos de las viviendas, (La Tercera, 18-06-2007). 
En la línea anterior y nuevamente alejándose de las formulaciones prácticas del Plan Maestro Urbano, esta vez incorporando la idea de la integración social, se elabora el $1^{\circ}$ Concurso de arquitectura e integración social. Comunidades de Ingresos Diversos en CPB, organizado por CPB-MINVU, en conjunto con la Facultad de Arquitectura y Urbanismo de la Universidad de Chile y la Facultad de Arquitectura, Diseño y Estudios Urbanos de la P. Universidad Católica de Chile. Este concurso enuncia en sus bases el objetivo de reflexionar y proponer nuevas formas de enfrentar los proyectos de Comunidades de CPB, a través de la innovación y desarrollo de propuestas de diseño y gestión social-económica que puedan ser implementadas e incorporadas como criterios para las políticas públicas de vivienda, orientadas a la integración social y generación de comunidades de ingresos diversos (CID). Este concurso público de ideas interdisciplinario, otorga importancia a tres dimensiones: la urbano-arquitectónica, la social y la económica, y plantea como objetivos específicos: generar un impulso a un modelo replicable de vivienda y desarrollo urbano que pueda sustentarse en el actual contexto, dando garantías de su puesta en práctica; y servir de base para las futuras licitaciones en CPB, en las cuales se fomente esta nueva tipología de desarrollo urbano. Según sus bases se busca crear un modelo sustentable para el desarrollo de CID en $\mathrm{CPB}$, mediante el desarrollo de un conjunto de viviendas que incluya un $10 \%$ de unidades correspondientes al Fondo Solidario Vivienda I (FSV I), un mínimo de $20 \%$ y un máximo de $40 \%$ de unidades FSV II y un mínimo de $30 \%$ de viviendas de mercado de 1300 UF o más. Ello en una zona habitacional mixta con una densidad bruta: 150 a 600 hab/há. con un coeficiente de ocupación de Suelo: $60 \%$ y una constructibilidad de 2,4 en el lote que indica la imagen abajo, de cinco hás.

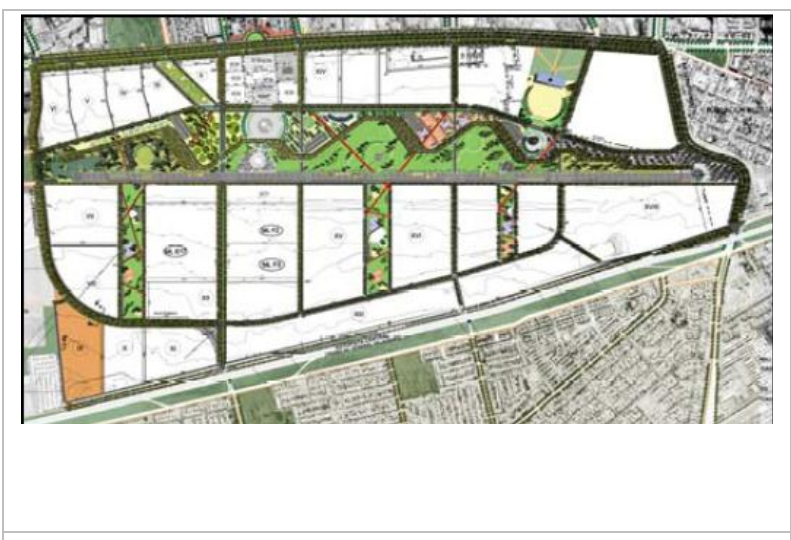

Anexo2.- Fig.7.- Ubicación concurso CID, CPB.

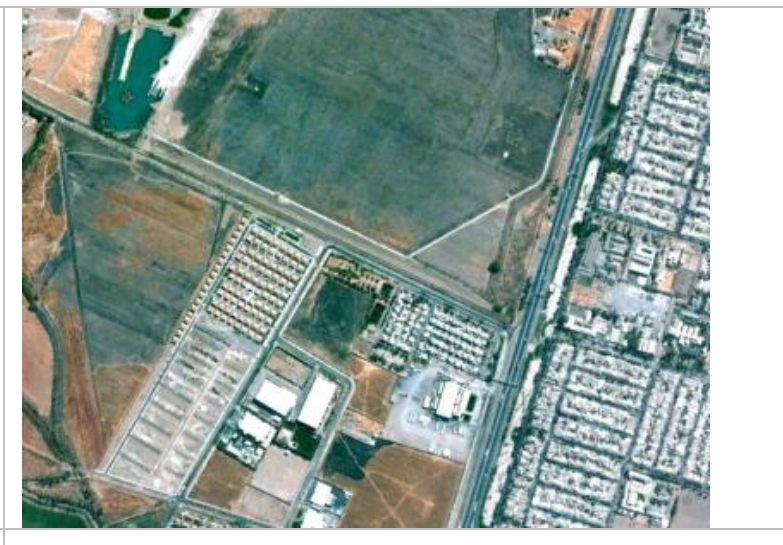

Anexo2.- Fig. 8.- contexto lote planteado para el concurso.

Respecto de este concurso cabe resaltar la ubicación del paño escogido, el que corresponde a un retazo de esquina que se vincula a áreas ya urbanizadas con vivienda de uno y dos pisos, por lo que la respuesta no solo debiese diferenciarse de lo existente sino enlazarse adecuadamente. La respuesta a este paño correspondería a un ejemplo modélico de lo que se espera para los barrios de C.P.B., lamentablemente el concurso presentó unos montos bajísimos asociados a los premios y unos requerimientos de equipo que limitaron la participación de grupos de profesionales y la participación internacional.

El jurado3 otorgó el primer lugar al equipo de Álvaro Arancibia, arquitecto; Andrés Elton, arquitecto; Ignacia Moreno, sicóloga; Santiago Edwards, cientista político y Eduardo Pérez, ingeniero civil, que presentó un proyecto de 368 viviendas (densidad de 73,6 viviendas/há, lo que equivale aproximadamente a una densidad de 350 hab/há) conformado por viviendas ampliables y pasajes peatonales de fachada continúa. El proyecto plantea estacionamientos de automóviles semienterrados, lo que permite disponer del espacio público a nivel de superficie para generar interacción entre los vecinos en pasajes peatonales, otro de los aspectos destacados por el jurado son los $16.440 \mathrm{~m} 2$ de áreas verdes y los espacios para comercio y equipamientos: un jardín infantil y un gimnasio.

3 Constituido por Paulina Saball, Luis Eduardo Bresciani, Patricio Gross, Cristián Fernández Cox, Germán Bannen, Francisco Sabatini, Paola Jirón, Ana Sugranyes, Pablo Trivelli. 
REVISTA DE

\section{URBANISMO}

ISSN 0717-5051

http://revistas.uchile.cl/index.php/RU/index

Revista de Urbanismo N²2 - Junio de 2010 Departamento de Urbanismo - FAU - Universidad de Chile

El diseño plantea cuatro modelos de casas, dirigidas a familias con distintos ingresos, agrupadas en bloques de tres niveles y medio, organizados paralelamente en sentido norte sur. El comercio y servicios aparece concentrado y asociado al borde de la carretera, y entre cada bloque se disponen espacios de uso peatonal exclusivo desapareciendo la calle vehicular como parte de la estructura urbana interior, el automóvil transita únicamente por los límites del predio. En el conjunto los bloques están agrupados en dos áreas separadas por un paseo a modo de parque.
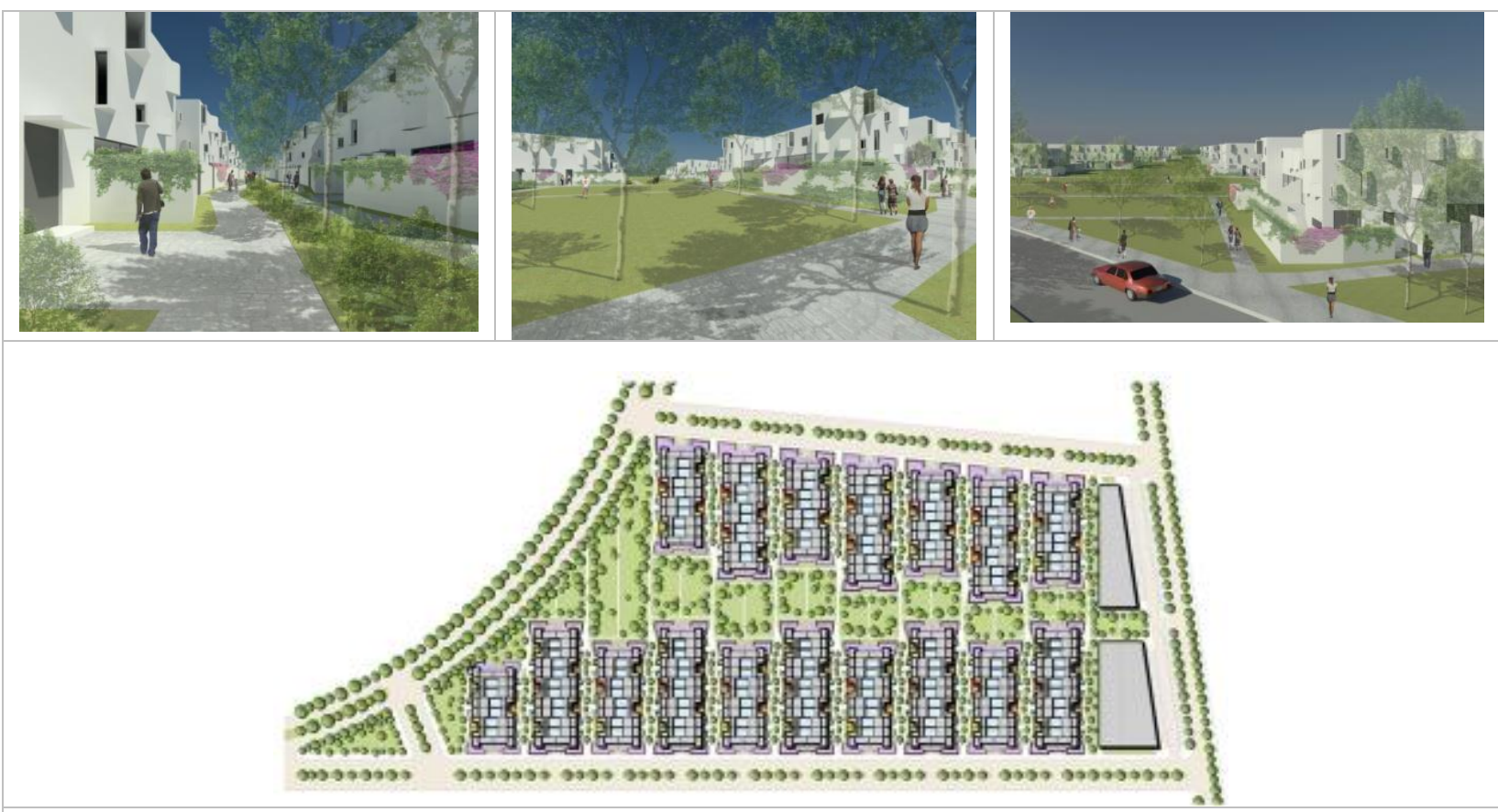

Anexo 2.- Figs.9, 10 y 11.-

Este proyecto, a juicio del autor, incorpora adecuadamente el tema de la inclusión de comunidades de ingresos diversos, con una imagen urbana atractiva, e innovaciones respecto la definición de espacios de administración comunitaria para el resguardo colectivo de vehículos motorizados, aspectos que resultan muy interesantes. Sin embargo, no presenta vinculación alguna respecto de la estructuración de los barrios planteada por el proyecto "Ciudad del Viento", adoleciendo de los aspectos que estos planteaban para el logro de los objetivos del desarrollo urbano sostenible.

Si bien es un proyecto atractivo en términos de imagen y distribución del programa a nivel de arquitectura de los bloques, sobre todo al considerar estacionamientos subterráneos y liberar el espacio para la circulación peatonal, tiene una carente diferenciación urbana a nivel local, desaprovechando la oportunidad de generar economías de escala barrial, y posee una mala vinculación del espacio público con el espacio residencial, pues niega en el primer y en el segundo piso, la relación vivienda - espacio público, al disponer fachadas fundamentalmente cerradas al resguardo del espacio público, olvidando las recomendaciones básicas sobre seguridad de medios residenciales. Si sumamos a ello un resultado homogéneo en distribución de usos de suelo, o posibilidades de su alteración, obtenemos un ejemplo de no diversidad y no activación del espacio público, a pesar de que las superficies estén destinadas para ello.

Otro aspecto cuestionable, es la orientación de los bloques, la que es contrapuesta a la orientación trabajada en "Ciudad del Viento" y definida para optimizar el uso solar. Se considera que la disposición de este tipo de bloques en sentido norte sur, a las distancias manejadas disminuye las posibilidades de recurrir a sistemas pasivos de calefacción de la vivienda y limita la eficiencia energética de la misma.

Habiendo revisado todos estos proyectos en el proceso de evolución y mutación de la idea original de Portal Bicentenario y su transformación en C.P.B., cabe preguntarse por la coherencia en el desarrollo de este tipo de propuestas. Pareciese que la estructuración de un Concurso de Ideas para elegir una idea rectora, validada por una comunidad disciplinar, y 
REVISTA DE

URBANISMO

ISSN 0717-5051

http://revistas.uchile.cl/index.php/RU/index

Revista de Urbanismo N²2 - Junio de 2010 Departamento de Urbanismo - FAU - Universidad de Chile

consensuada por un equipo de expertos, y luego la posterior elaboración de un Plan Maestro rector, que funcione como carta de navegación no asegura la definición ni de la imagen ni de la voluntad y objetivos del proyecto. Pareciese que la flexibilidad de la herramienta Plan Maestro Urbano, dejase en un intersticio muy amplio la definición concreta del futuro de este tipo de operaciones, un intersticio tan amplio, que la operación completa puede ser aún después de ya empezada las obras, detenida y cuestionada.

A juicio del autor, el vuelco conceptual al que es sometido a la iniciativa desde la designación del proyecto ganador del Concurso de Ideas en 2001, es, ante la comunidad internacional, un mensaje que atenta contra la credibilidad de las estrategias de desarrollo urbano propiciadas por el Estado, y genera incertidumbre para la inversión en este tipo de proyectos. Ello sobretodo, dada la amplia convocatoria internacional que tuvo el Concurso de Ideas. Intencionadamente en esta comunicación no se tocan aspectos legales o de factibilidad estratégica para este proyecto, centrándose únicamente en aspectos de tipo urbanístico. Se considera que todos estos aspectos debiesen haber estado incorporados en el desarrollo de la propuesta desde el comienzo. Y se estima que una coherencia en el desarrollo desde el Concurso de Ideas a la implementación del proyecto hubiese coadyuvado a blindar a la propuesta políticamente e inclusive comunicacionalmente, otorgando incluso la posibilidad de obtención de recursos para su desarrollo.

Se estima que el vuelco conceptual que el Plan Maestro genera en el proyecto, más allá de los cambios formales del mismo, genera una identificación del emprendimiento con una iniciativa inmobiliaria más, y no con un proyecto emblemático a la escala del Bicentenario de la República. Este vuelco se refrenda con el cambio en el discurso comunicacional del proyecto el que ya en 2004 se anuncia como un nuevo modelo de gestión para megaproyectos desarrollados desde el Estado, haciendo menos énfasis en la capacidad de este proyecto de generar un "nuevo modelo de ciudad" y no solamente un "nuevo modo de hacer ciudad".

Se estima que, inclusive con una adecuada propuesta de gestión de los terrenos, pudiese haberse evitado los conflictos legales del proyecto, por ejemplo, manteniendo la propiedad pública de los terrenos, idea planteada, si bien no desarrollada, en el proyecto "Ciudad del Viento". Si bien estas alternativas fueron someramente analizadas al momento de estructurar el Plan Maestro, no se realizaron análisis profundos dados los plazos y montos involucrados en dicha licitación y sobretodo dada la dificultad de romper los paradigmas con los que opera el consorcio de empresas que se adjudicó el desarrollo del Plan Maestro. Al respecto cabe resaltar que todos los estudios de mercado y de tendencias de localización realizados durante la elaboración del Plan Maestro, se manejan dentro de los paradigmas tradicionales de los operadores inmobiliarios, y tendencias del mercado ya existentes en 2003, además consideran la necesidad de generar montos predefinidos de recursos económicos con el proyecto, escenarios claramente adversos para este tipo de propuestas. Por otra parte en ningún momento se evalúa la captación de recursos financieros por mercados alternativos relacionados con la sustentabilidad ambiental de la propuesta, (desde bonos de carbono, concursos de fondos internacionales provenientes de organismos multilaterales, así como la captación directa desde organizaciones no gubernamentales transnacionales interesadas en hacer aportes, hasta la participación de la que otrora donara los terrenos para el aeródromo, entre otros). 